\title{
Mass Balance, Meteorological, Ice Motion, Surface Altitude, and Runoff Data at Gulkana Glacier, Alaska, 1993 Balance Year
}

by Rod S. March and Dennis C. Trabant

U.S. GEOLOGICAL SURVEY

Water-Resources Investigations Report 96-4299

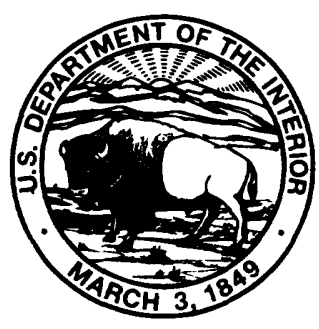




\section{U.S. DEPARTMENT OF THE INTERIOR \\ BRUCE BABBITT, Secretary \\ GEOLOGICAL SURVEY \\ Gordon P. Eaton, Director}

For additional information write to:

District Chief

U.S. Geological Survey

4320 University Drive, Suite 201

Anchorage, AK 99508-4664
Copies of this report can be purchased from:

U.S. Geological Survey

Branch of Information Services

Box 25286

Denver, CO 80225-0286

http://www-water-ak.usgs.gov 


\section{CONTENTS}

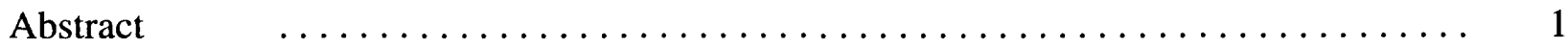

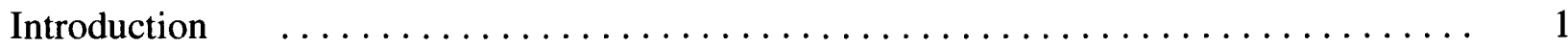

Description of the Gulkana Glacier Basin and its Climate ............... 2

Measurement System and Terminology ......................... 3

1993 Data Collection . . . . . . . . . . . . . . . . . . . . . . . . . 8

Field Visits. .................................... 8

Recorded Variables .............................. 8

Air Temperature .................................. 8

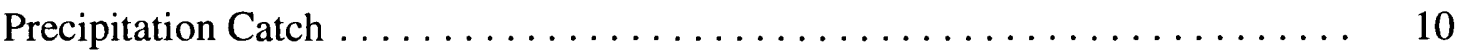

Runoff........................................ 11

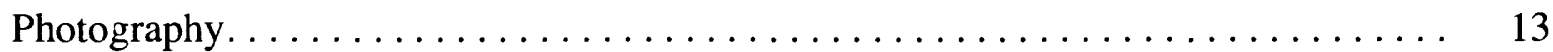

1993 Mass Balance Evaluation . . . . . . . . . . . . . . . . . . . . . . 14

Mass Balance Measurement Errors. . . . . . . . . . . . . . . . . . . . . 14

Balance at Specific Sites . . . . . . . . . . . . . . . . . . . . . . 15

Area-Averaged Balances............................... 19

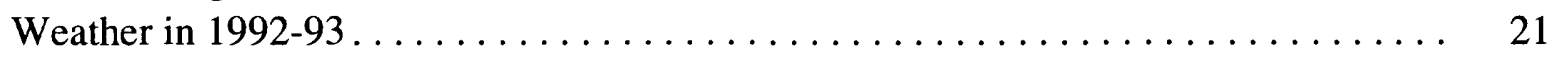

Measured and Maximum Winter Snow Balances ................... 21

Net Balance ....................................... 21

Summer Balance ................................... 23

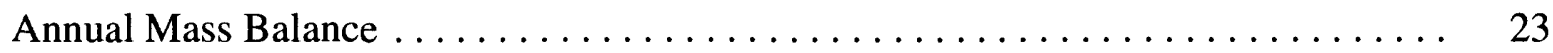

Accumulation Area Ratio and Equilibrium Line Altitude $\ldots \ldots \ldots \ldots \ldots \ldots . . \ldots 23$

Ice Motion Measurement and Errors . . . . . . . . . . . . . . . . . . . . 24

Glacier Surface Altitude Measurement and Errors . . . . . . . . . . . . . . . . . 26

References cited .................................... 29

\section{FIGURES}

1. Map of the Gulkana Glacier basin, Alaska..................... 3

2-7. Graphs showing:

2. Area-altitude distribution of Gulkana Glacier in $1967 \ldots \ldots \ldots \ldots \ldots \ldots$

3. Time distribution of index-site mass balance................... 6

4. Time distribution of glacier-averaged mass balance $\ldots \ldots \ldots \ldots \ldots \ldots \ldots 7$

5. Daily mean air temperature recorded at 1,480 meters altitude . . . . . . . . 10

6. Daily runoff from Phelan Creek near Paxson. . . . . . . . . . . . . . . 12

7. Estimated daily runoff from Phelan Creek near Paxson............... 14

\section{TABLES}

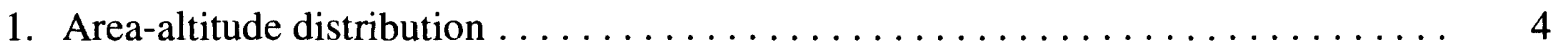

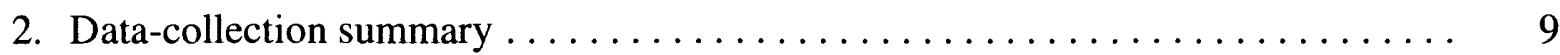

3. Daily and monthly mean air temperature $\ldots \ldots \ldots \ldots \ldots \ldots \ldots \ldots \ldots . \ldots \ldots$ 


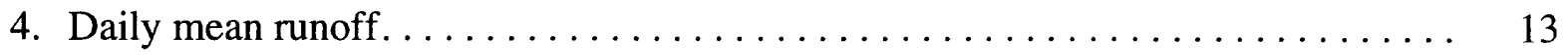

5. Stake readings, snow depths, and snow density data for sites A, B, and D . . . . 16

6. Snow temperature, firn thickness, and firn density data for sites A, B, and D. . . 17

7. Ice data and mass balance calculations for sites A, B, and D . . . . . . . . . 18

8. Site and area-integrated balance quantities. ....................... 22

9. Stake locations, lean corrections, and ice motion................. 25

10. Glacier surface altitude measurements and analysis at index sites.......... 27

11. Continuation of glacier surface altitude measurements

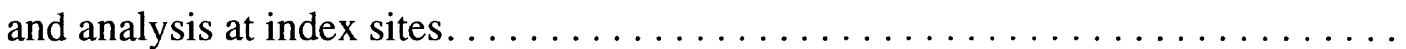

\section{CONVERSION FACTORS, VERTICAL DATUM, AND SYMBOLS}

\begin{tabular}{rll}
\hline Multiply & By & To obtain \\
millimeter $(\mathrm{mm})$ & 0.03937 & inch \\
centimeter $(\mathrm{cm})$ & 0.3937 & inch \\
meter $(\mathrm{m})$ & 3.281 & foot \\
kilometer $(\mathrm{km})$ & 0.6214 & mile \\
square kilometer $\left(\mathrm{km}^{2}\right)$ & 0.3861 & square mile \\
kilogram $(\mathrm{kg})$ & 2.205 & pound, avoirdupois \\
gram $(\mathrm{gm})$ & 0.035 & ounce, avoirdupois \\
kilograms per liter $(\mathrm{kg} / \mathrm{L})$ & 62.43 & pound per cubic foot \\
kilograms per cubic meter $\left(\mathrm{kg} / \mathrm{m}^{3}\right)$ & 0.06243 & pound per cubic foot \\
meters per year $(\mathrm{m} / \mathrm{yr})$ & 3.281 & feet per year \\
millimeters per day $(\mathrm{mm} / \mathrm{d})$ & 0.039 & inches per day \\
$\mathrm{grads}$ & 0.9 & degrees \\
joule & 0.2389 & calorie \\
degree Celsius $\left({ }^{\circ} \mathrm{C}\right)$ & ${ }^{\circ} \mathrm{F}=1.8 \mathrm{x}{ }^{\circ} \mathrm{C}+32$ & degree Fahrenheit $\left({ }^{\circ} \mathrm{F}\right)$ \\
& & \\
\hline
\end{tabular}

\section{Vertical Datum:}

Altitudes are measured relative to the National Geodetic Vertical Datum of 1929 (NGVD of 1929) which is defined as follows: A geodetic datum, formerly called SEA LEVEL DATUM OF 1929, derived from a general adjustment of the first-order level nets of both the United States and Canada. In the adjustment, sea levels from selected TIDE stations in both countries were held fixed. The year indicates the time of the last general adjustment. This datum should not be confused with MEAN SEA LEVEL. Altitudes are the same in both the local coordinate system and the Universal Transverse Mercator system.

\section{Symbols used in this report:}

$A \quad$ area, in square meters

$A_{B} \quad$ basin area, in square kilometers

$A_{G} \quad$ glacier area, in square kilometers

AAR accumulation area ratio 
$b \quad$ area-averaged balance value

$b^{\prime} \quad$ average stake height of the glacier surface within a 25-75 meter radius of the stake, in meters

$b^{\prime}$ ss $_{1} \quad$ average stake height of the first summer surface down from the glacier surface within a 25-75 meter radius of the stake, in meters

$b^{\prime} \mathrm{ss}_{2} \quad$ average stake height of the second summer surface down from the glacier surface within a 25-75 meter radius of the stake, in meters

$b_{0}{ }^{\prime} \mathrm{ss}_{1} \quad$ initial stake height at the beginning of the measurement year of the first summer surface down from the glacier surface within a 25-75 meter radius of the stake, in meters

$b_{0}{ }^{\prime} \mathrm{ss}_{2} \quad$ initial stake height at the beginning of the measurement year of the second summer surface down from the glacier surface within a 25-75 meter radius of the stake, in meters

$b^{*} \quad$ stake height of surveyed point near $b^{\prime}$ on the stake, in meters

$b^{* *} \quad$ calculated stake height of the glacier surface directly above the stake bottom (i.e. as if the stake were vertical), in meters

$b_{a} \quad$ annual balance at site

$\bar{b}_{a} \quad$ area-averaged annual balance

$b_{a}(\mathrm{f}) \quad$ long-term, average firn balance

$b_{a}(\mathrm{fi})$ annual firn and ice balance at site

$\bar{b}_{a}$ (fi) area-averaged annual firn and ice balance

$b_{a}(\mathrm{j}) \quad$ glacier-averaged annual internal ablation

$b_{n} \quad$ net balance at site

$\mathrm{b}_{\text {no }} \quad$ initial net balance

$\mathrm{b}_{n l} \quad$ late net balance

$\bar{b}_{n} \quad$ area-averaged net balance

$b_{s} \quad$ summer balance

$\bar{b}_{\mathrm{s}} \quad$ area-averaged summer balance

$b_{w} \quad$ winter balance

$\bar{b}_{w} \quad$ area-averaged winter balance

$b(\mathrm{f}) \quad$ firn balance at site

$b$ (i) ice balance at site

$b_{0}$ (i) initial ice balance at site

$b_{1}$ (i) final ice balance at site

$\bar{b}(\mathrm{k}) \quad$ area-averaged internal accumulation

$b_{a}(\mathrm{k})$ annual internal accumulation at site

$b$ (ls) late snow balance at site

$b_{1}(\mathrm{ls})$ final late snow balance at site

$b_{l}(\mathrm{ls})$ area-averaged final late snow balance

$b(\mathrm{~s}) \quad$ snow balance at site

$b_{0}(\mathrm{~s}) \quad$ initial snow balance at site

$\bar{b}_{0}(\mathrm{~s})$ area-averaged initial snow balance

$b_{m}(\mathrm{~s})$ measured winter snow balance at site

$\bar{b}_{m}(\mathrm{~s})$ area-averaged measured winter snow balance

$b_{w}(\mathrm{~s}) \quad$ maximum winter snow balance at site

$b_{w}(\mathrm{~s})$ area-averaged maximum winter snow balance

$d(\mathrm{~s}) \quad$ snow depth, in meters

$d(\mathrm{nf}) \quad$ new firn depth, in meters

$\Delta U_{I} \quad$ glacier-averaged change in potential energy per unit area per year from ice motion

$\Delta U_{W} \quad$ glacier-averaged change in potential energy per unit area per year from water flow

E UTM Easting

ELA equilibrium line altitude

$g_{a} \quad$ average annual precipitation-gage catch, in meters

$H_{t} \quad$ height of the stake upper target above the stake bottom as measured along the stake, in meters

HY hydrologic year; interval between October 1 and the end of the following September

$k \quad$ horizontal scale factor between the UTM plane and sea level

$k \quad$ mean horizontal scale factor between the UTM plane and sea level 
m

$\mathrm{m}_{\text {we }}$

$n$

$r_{a}$

$r_{a 67-78}$

$r_{G 67-78}$

$\mathrm{ss}_{1}$

$\mathrm{ss}_{2}$

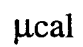

$X_{g} \quad$ local sea-level coordinate of measurement stake at glacier surface, in meters

$X_{L} \quad$ local sea-level coordinate, in meters

$X_{s} \quad$ local sea-level coordinate of bottom of measurement stake, in meters

$X_{t} \quad$ local sea-level coordinate of stake upper target, a point on the stake $1.5-2.0$ meters above the glacier surface, in meters

$Y_{g} \quad$ local sea-level coordinate of measurement stake at glacier surface, in meters

$Y_{L} \quad$ local sea-level coordinate, in meters

$Y_{s} \quad$ local sea-level coordinate of bottom of measurement stake, in meters

$Y_{t} \quad$ local sea-level coordinate of stake upper target, a point on the stake 1.5-2.0 meters above the glacier surface, in meters

$Z \quad$ altitude, in meters

$\mathrm{Z}_{\mathrm{ELA}} \quad$ numerical value for the altitude of the ELA

$Z_{g} \quad$ altitude of measurement stake at glacier surface, in meters

$Z_{i} \quad$ altitude of glacier surface at index site, in meters

$Z_{s} \quad$ altitude of bottom of measurement stake, in meters

$Z_{t} \quad$ altitude of stake upper target, a point on the stake 1.5-2.0 meters above the glacier surface, in meters

$Z_{\text {Terminus }}$ altitude of the terminus of the glacier, in meters

$d X Y Z$ total three-dimensional displacement of the stake bottom between measurements

$\theta \quad$ down dip direction with zero east and positive counterclockwise

$\phi \quad$ dip angle with zero horizontal and positive angles up 


\title{
Mass Balance, Meteorological, Ice Motion, Surface Altitude, and Runoff Data at Gulkana Glacier, Alaska, 1993 Balance Year
}

\author{
by Rod S. March and Dennis C. Trabant
}

\begin{abstract}
The 1993 measured winter snow, maximum winter snow, net, and annual balances in the Gulkana Glacier basin were evaluated on the basis of meteorological, hydrological, and glaciological data measured in the basin and are reported herein. Averaged over the glacier, the measured winter snow balance was 0.81 meter on March 31, 1993, 1.2 standard deviations below the long-term average; the maximum winter snow balance, 0.84 meter, was reached on May 10, 1993 and remained until May 11, 1993; the net balance (from August 18, 1992 to September 8, 1993) was -1.80 meters, the most negative balance year on record at 2.8 standard deviations below the longterm average. The annual balance (October 1, 1992 to September 30, 1993) was -1.64 meters. Icesurface motion and altitude changes measured at three index sites document seasonal ice speed and glacier thickness changes. Annual stream runoff was 1.996 meters averaged over the basin, 0.2 standard deviations above the long-term average.
\end{abstract}

\section{INTRODUCTION}

The U.S. Geological Survey has a long-term program to monitor climate, glacier motion, mass balance, and stream runoff to understand glacier-related hydrologic processes for improving the quantitative prediction of water resources, glacier-related hazards, and the consequences of global change (Fountain and others, 1997). The approach has been to establish long-term mass balance monitoring programs at three widely spaced glacier basins in the United States that clearly sample different climate-glacier-runoff regimes. Gulkana Glacier is one of three long-term, highquality mass balance monitoring sites operated by the U.S. Geological Survey. The other monitoring sites are Wolverine Glacier in southcentral Alaska and South Cascade Glacier in Washington. This report contains the mass balance, meteorological, ice motion, surface altitude, and basin runoff measurements made in the Gulkana Glacier basin during 1993 as part of the long-term monitoring program.

Measurements began on Gulkana Glacier during the early 1960's with the University of Alaska Gulkana Glacier Project (Péwé and Reger, 1983). For several years this project measured the energy budget, mass balance, meteorology, foliation, flow, and glacier bottom topography (from gravity anomalies) at Gulkana Glacier. In 1966, a continuing series of meteorological, snow and ice balance, and runoff measurements was begun by the U.S. Geological Survey as part of the United States contribution to the International Hydrologic Decade study of mass balances on selected glaciers. Detailed results from 1966 and 1967 are reported by Meier and others (1971) and Tangborn and others (1977), respectively. Measured winter snow balance and annual balance from 1966-77 are reported by Meier and others (1980). Balance studies were relatively intensive until 
the mid-1970's, after which spatial sampling was reduced to three sites used as an index for mass balance. Measurements at the three remaining sites were expanded to include ice motion and surface altitude observations (for glacier volume change) in addition to the balance, runoff, and meteorological observations previously being made. Since 1966, part of the Gulkana data set (net balance, accumulation, ablation, accumulation area ratio (AAR), and equilibrium line altitude (ELA)) has been published by the World Glacier Monitoring Service (Kasser, 1967; Muller, 1977; Haeberli, 1985; Haeberli and Müller, 1988; Haeberli and Hoelzle, 1993). Index-site glacier-surface and summer-surface altitudes, measured winter balance, and net firn and ice balance from 1975 to 1983 are reported by Mayo and Trabant (1986). Data for 1992 similar to those presented here were published by March and Trabant (1996).

A limited portion of the glacier data (preliminary annual values of balance, temperature, and runoff data) for the period of record is available on the Internet by looking on the Alaska District, Water Resources Division home page (currently http://www-water-ak.usgs.gov) ${ }^{1}$.

The Gulkana record is approaching the 30-year length-of-record criterion (generally considered necessary to provide reasonable statistics) used in the selection of stations for international exchange through the Global Telecommunications Service (GTS) for global climate monitoring (Karl and others, 1989). By this criterion, the current record is marginally valuable for long-term analysis. Interpretations of regional climate-glacier relations using the Gulkana data include papers by Fahl (1973), by Walters and Meier (1989), and by Letréguilly and Reynaud (1989).

\section{Description of the Gulkana Glacier Basin and its Climate}

Gulkana Glacier (fig. 1) (lat $63^{\circ} 16^{\prime}$ N., long $145^{\circ} 25^{\prime}$ W.) is a compound valley glacier fed from several cirques on the south flank of the eastern Alaska Range. The glacier and basin areaaltitude distributions (table 1; fig. 2) were defined for the 1967 balance analysis (Tangborn and others, 1977). These values are used throughout this report. In 1967 , the $31.6-\mathrm{km}^{2}$ basin was 70 percent covered by perennial snow and ice. Gulkana Glacier is the largest glacier in the basin covering $19.32 \mathrm{~km}^{3}$. The basin also contains Pegmatite Glacier (fig. 1), three small, unnamed glaciers, and perennial snow and ice patches that had a total area of $2.9 \mathrm{~km}^{2}$ in 1967 . The accumulation region of Gulkana Glacier consists of four adjacent cirques with east, south, and west exposures reaching as high as 2,470 $\mathrm{m}$ altitude. The cirque glaciers converge forming a south-southwest-flowing ablation area with a terminus lightly covered with rock-debris (cover photo) at $1,160 \mathrm{~m}$ altitude. Slightly contorted moraines suggest that Gulkana Glacier has surged (see cover photo). However, no flow instabilities have been detected since scientific investigation began in the early 1960's. Gulkana Glacier has been in general recession since the culmination of its last advance around the turn of the century (Péwé and Reger, 1983). The total recession since then has been about $3 \mathrm{~km}$.

Phelan Creek drains the Gulkana Glacier basin and flows into the Delta River, which is a tributary of the Tanana River, and finally into the Yukon River north of the Alaska Range. In the past, Phelan Creek occasionally drained into Summit Lake at the head of the Gulkana and Copper Riv-

\footnotetext{
${ }^{1}$ Because of the rapidly evolving nature of the Internet, it is recognized that the Internet references in this report may change. In that event, the reader may alternatively find the information referenced by starting higher in the Internet hierarchy of the Survey at either the Water Resources Division (http://water.usgs.gov) or the U.S. Geological Survey at (http://www.usgs.gov).
} 
ers. The alternating drainage was diverted into the Yukon River basin when the Richardson Highway was constructed in 1923.

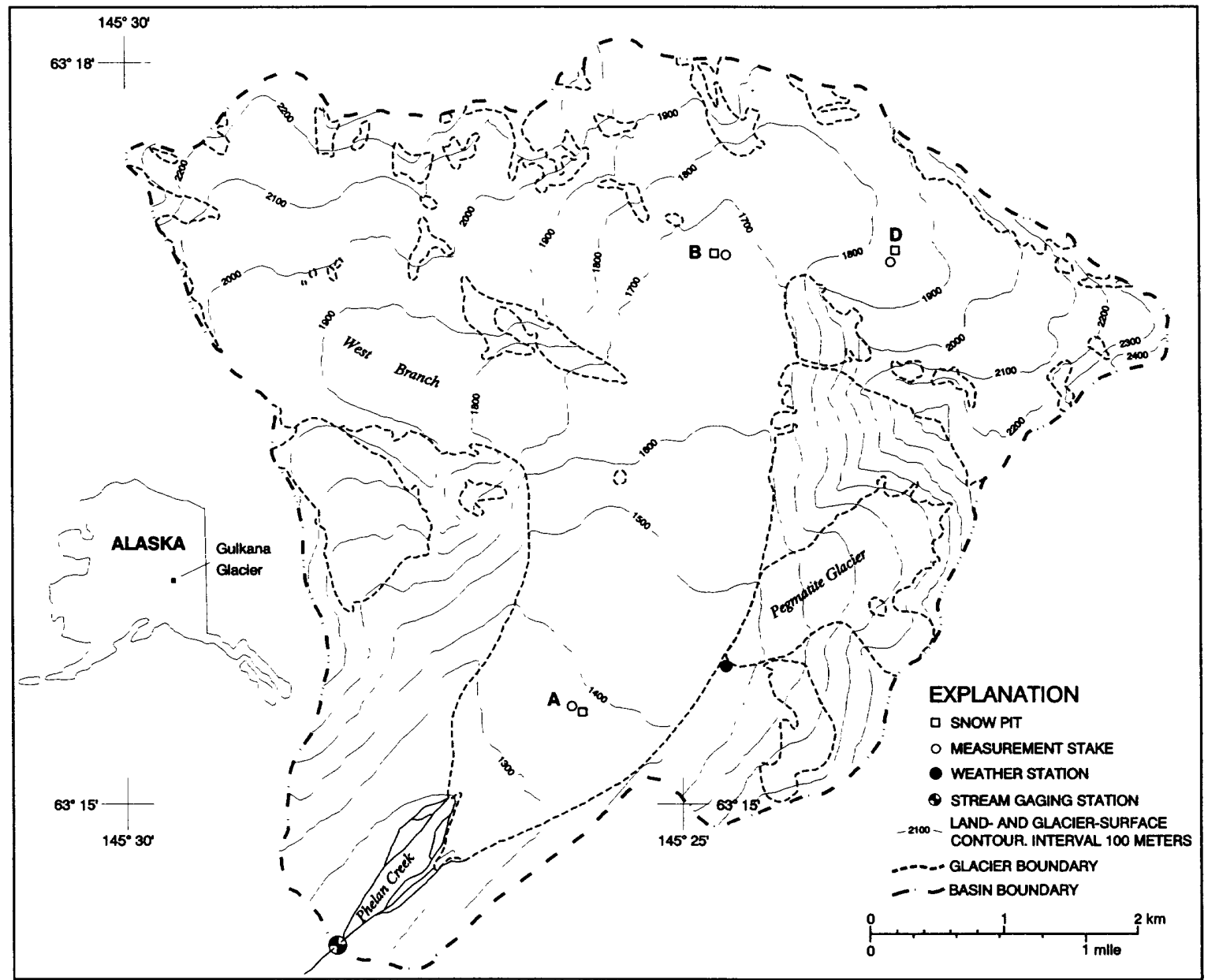

Base map, including glacier contours and boundary, from Tangborn and others, 1977.

Figure 1. Gulkana Glacier basin, Alaska.

The mean ELA is near $1,760 \mathrm{~m}$, which is consistent with a continental mountain climate. The mean annual air temperature near the ELA is about $-6^{\circ} \mathrm{C}$, lapsed from the recorder site using the wet adiabatic rate of $-6.6^{\circ} \mathrm{C}$ per $1,000 \mathrm{~m}$. The mean annual air temperature at the recorder site at $1,480 \mathrm{~m}$ altitude is about $-4^{\circ} \mathrm{C}$, and the average annual precipitation-gage catch is about $1 \mathrm{~m}$. Daily mean temperatures range from a low of $-35^{\circ} \mathrm{C}$ to a high of $15^{\circ} \mathrm{C}$. The average annual basin runoff for water years $1967-78$ and $1989-93$ is $1.90 \mathrm{~m}$.

\section{Measurement System and Terminology}

Seasonal monitoring on Gulkana Glacier consists of three basic measurements: surface mass balance, ice velocity, and surface altitude. These measurements are made repeatedly at three fixed locations on Gulkana Glacier, referred to as the "index sites" (labeled A, B, and D on figure 1). Balance-motion stakes maintained near each index site support the long-term data collection. 
Table 1. Area-altitude distribution of Gulkana Glacier and Gulkana Glacier basin by 100-meter altitude intervals as defined for the 1967 balance analysis (Tangborn and others, 1977)

[m, meters; $\mathrm{km}^{2}$, square kilometers]

\begin{tabular}{|c|c|c|c|c|c|c|c|c|c|}
\hline \multirow[b]{2}{*}{$\begin{array}{c}\text { Altitude } \\
\text { interval } \\
\text { (m) }\end{array}$} & \multirow[b]{2}{*}{$\begin{array}{c}\text { Average } \\
\text { altitude } \\
(\mathrm{m})\end{array}$} & \multirow[b]{2}{*}{$\begin{array}{l}\text { Basin } \\
\text { area } \\
\left(\mathrm{km}^{2}\right) \\
\end{array}$} & \multirow{2}{*}{$\begin{array}{c}\text { Non- } \\
\text { glacier } \\
\text { area } \\
\left(\mathrm{km}^{2}\right)\end{array}$} & \multirow{2}{*}{$\begin{array}{c}\text { Total } \\
\text { glacier } \\
\text { area } \\
\left(\mathrm{km}^{2}\right)\end{array}$} & \multirow{2}{*}{$\begin{array}{c}\text { Gulkana } \\
\text { Glacier } \\
\text { area } \\
\left(\mathrm{km}^{2}\right) \\
\end{array}$} & \multirow{2}{*}{$\begin{array}{l}\text { Other } \\
\text { glacier } \\
\text { area } \\
\left(\mathrm{km}^{2}\right) \\
\end{array}$} & \multicolumn{3}{|c|}{$\begin{array}{c}\text { Sub-areas of glacier } \\
\text { represented } \\
\text { by index sites: }\end{array}$} \\
\hline & & & & & & & $\begin{array}{r}\text { Site A } \\
1373 \\
\left(\mathrm{~km}^{2}\right) \\
\end{array}$ & $\begin{array}{c}\text { Site B } \\
1685 \\
\left(\mathrm{~km}^{2}\right) \\
\end{array}$ & $\begin{array}{r}\text { Site D } \\
1837 \\
\left(\mathrm{~km}^{2}\right) \\
\end{array}$ \\
\hline $1,161-1,200$ & 1,181 & 0.84 & 0.72 & 0.12 & 0.12 & & 0.12 & & \\
\hline $1,200-1,300$ & 1,250 & 1.48 & 0.96 & 0.52 & 0.52 & & 0.52 & & \\
\hline $1,300-1,400$ & 1,350 & 1.92 & 0.72 & 1.20 & 1.20 & & 1.20 & & \\
\hline $1,400-1,500$ & 1,450 & 2.68 & 1.04 & 1.64 & 1.56 & 0.08 & 1.56 & & \\
\hline $1,500-1,600$ & 1,550 & 2.44 & 0.72 & 1.72 & 1.36 & 0.36 & 0.39 & 0.97 & \\
\hline $1,600-1,700$ & 1,650 & 3.68 & 0.92 & 2.76 & 2.12 & 0.64 & & 2.12 & \\
\hline $1,700-1,800$ & 1,750 & 4.00 & 1.08 & 2.92 & 2.04 & 0.88 & & 1.24 & 0.80 \\
\hline $1,800-1,900$ & 1,850 & 4.28 & 1.00 & 3.28 & 2.72 & 0.56 & & & 2.72 \\
\hline $1,900-2,000$ & 1,950 & 4.32 & 1.04 & 3.28 & 2.92 & 0.36 & & & 2.92 \\
\hline $2,000-2,100$ & 2,050 & 2.72 & 0.40 & 2.32 & 2.28 & 0.04 & & & 2.28 \\
\hline $2,100-2,200$ & 2,150 & 1.92 & 0.48 & 1.44 & 1.44 & & & & 1.44 \\
\hline $2,200-2,300$ & 2,250 & 1.04 & 0.24 & 0.80 & 0.80 & & & & 0.80 \\
\hline $2,300-2,400$ & 2,350 & 0.24 & 0.04 & 0.20 & 0.20 & & & & 0.20 \\
\hline \multirow[t]{3}{*}{$2,400-2,473$} & 2,437 & 0.04 & & 0.04 & 0.04 & & & & 0.04 \\
\hline & Total area & 31.60 & 9.36 & 22.24 & 19.32 & 2.92 & 3.79 & 4.33 & 11.20 \\
\hline & age altitude & 1,748 & 1,647 & 1,790 & 1,797 & 1,743 & 1,393 & 1,656 & 1,988 \\
\hline \multicolumn{3}{|c|}{ Upper altitude limit of zone $=$} & & & & & 1,529 & 1,761 & 2,473 \\
\hline \multicolumn{3}{|c|}{ Lower altitude limit of zone $=$} & & & & & 1,161 & 1,529 & 1,761 \\
\hline \multicolumn{3}{|c|}{$\begin{aligned} \text { Percent of Gulkana Glacier area } & = \\
\text { Percent of basin area } & =100 \%\end{aligned}$} & $30 \%$ & $70 \%$ & $61 \%$ & $9 \%$ & $19.6 \%$ & $22.4 \%$ & $58.0 \%$ \\
\hline
\end{tabular}

The combined mass balance system of measurement and reporting terminology (Mayo, Meier, and Tangborn, 1972) is adhered to in this report, with the addition of internal accumulation (Trabant and Mayo, 1985) and internal ablation (explained later in the "Area-Averaged Balances" section). The combined mass balance system is based on measurements relative to time-transgressive stratigraphic horizons (summer surfaces) and evaluation of adjustment quantities for determining the maximum winter balance, net balance, and fixed-date annual balance. Both net (stratigraphic) and annual (fixed-date) balances are derived from field measurements. The balance year used for the net mass balance is the interval between the minimum, glacier-wide mass balance in one year and the minimum, glacier-wide mass balance the following year. Thus, the net balance has a beginning and ending date. To calculate a true net balance it is necessary to run a simple balance model (explained later) to extrapolate from the nearest measurement to the time and value of the glacier-averaged net balance. In general, net balances reported in the literature are approximations in which the net balance is determined for each measurement location on the glacier as the difference between successive balance minimums at that location, and then combined as if the balance minimum occurred synchronously over the whole glacier. In most years, the balance minimum occurs at different times on different parts of the glacier (earlier high on the glacier and later low on the glacier), so that an area integration of the local balance minimums yields a pseudo areaaveraged balance that is not clearly defined with regard to time and does not represent the actual balance on the glacier at any moment. 


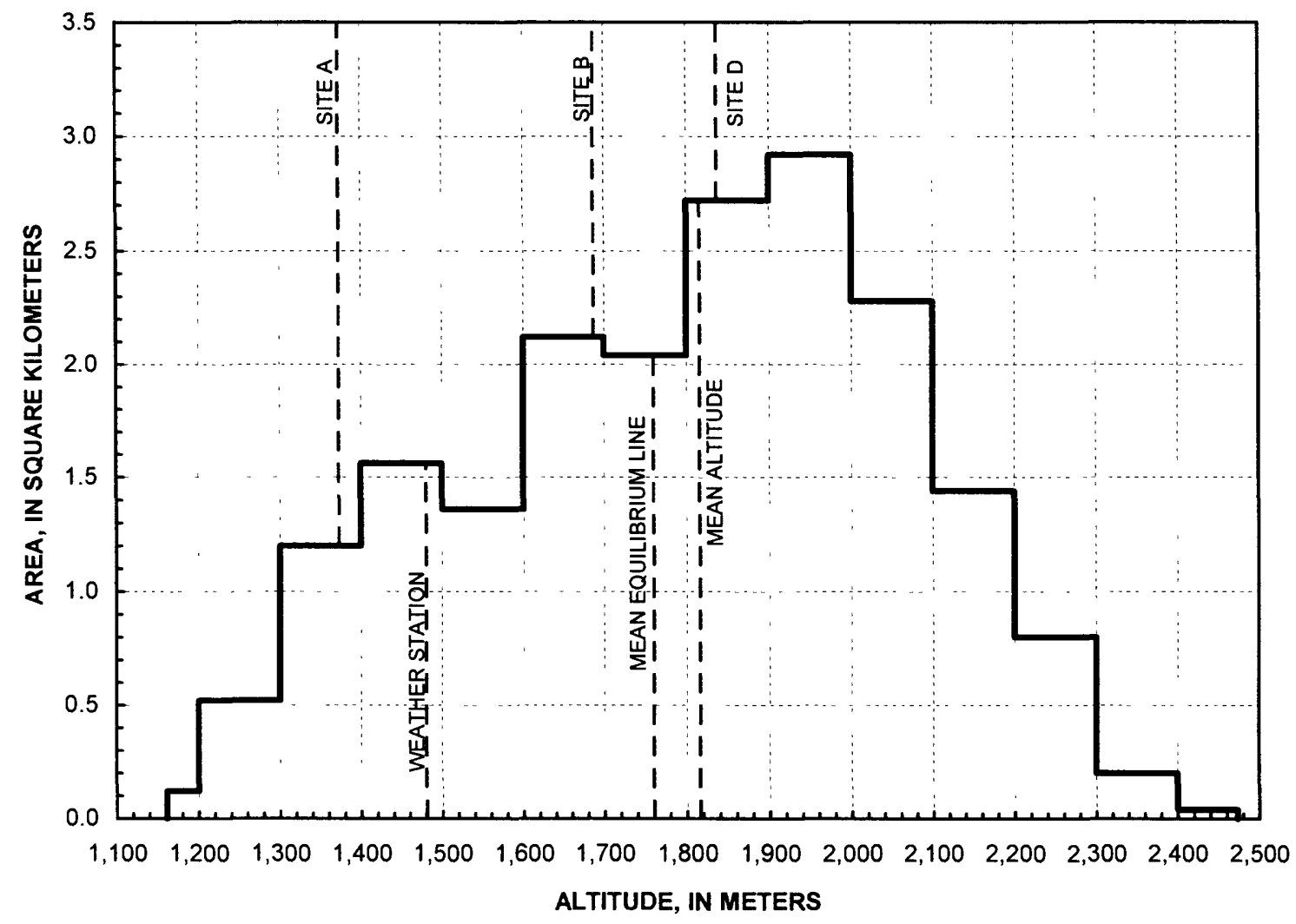

Figure 2. Area-altitude distribution of Gulkana Glacier in 1967 (Shown are altitudes of index sites, the weather station (air temperature and precipitation gage), the mean equilibrium line altitude, and mean glacier altitude).

The hydrologic year (HY), which is the period used for the annual (fixed-date) mass balance, is the interval between October 1 and the end of the following September. It is designated by the calendar year in which it ends. The hydrologic year coincides with the "water year" used for publishing U.S. Geological Survey hydrologic data. The temporal relation of the quantities defined and used for analyzing the index-site and glacier-averaged 1993 mass balances are illustrated in figures 3 and 4.

All balance, precipitation, and runoff values are reported in meters of water equivalent. Density values are reported in kilograms per liter and thus are numerically equivalent to the unitless relative density (the decimal fraction of the density of water). The density of water is assumed to be $1,000 \mathrm{~kg} / \mathrm{m}^{3}$ or $1 \mathrm{~kg} / \mathrm{L}$ and the relative density of glacier ice is assumed to be 0.9 . 


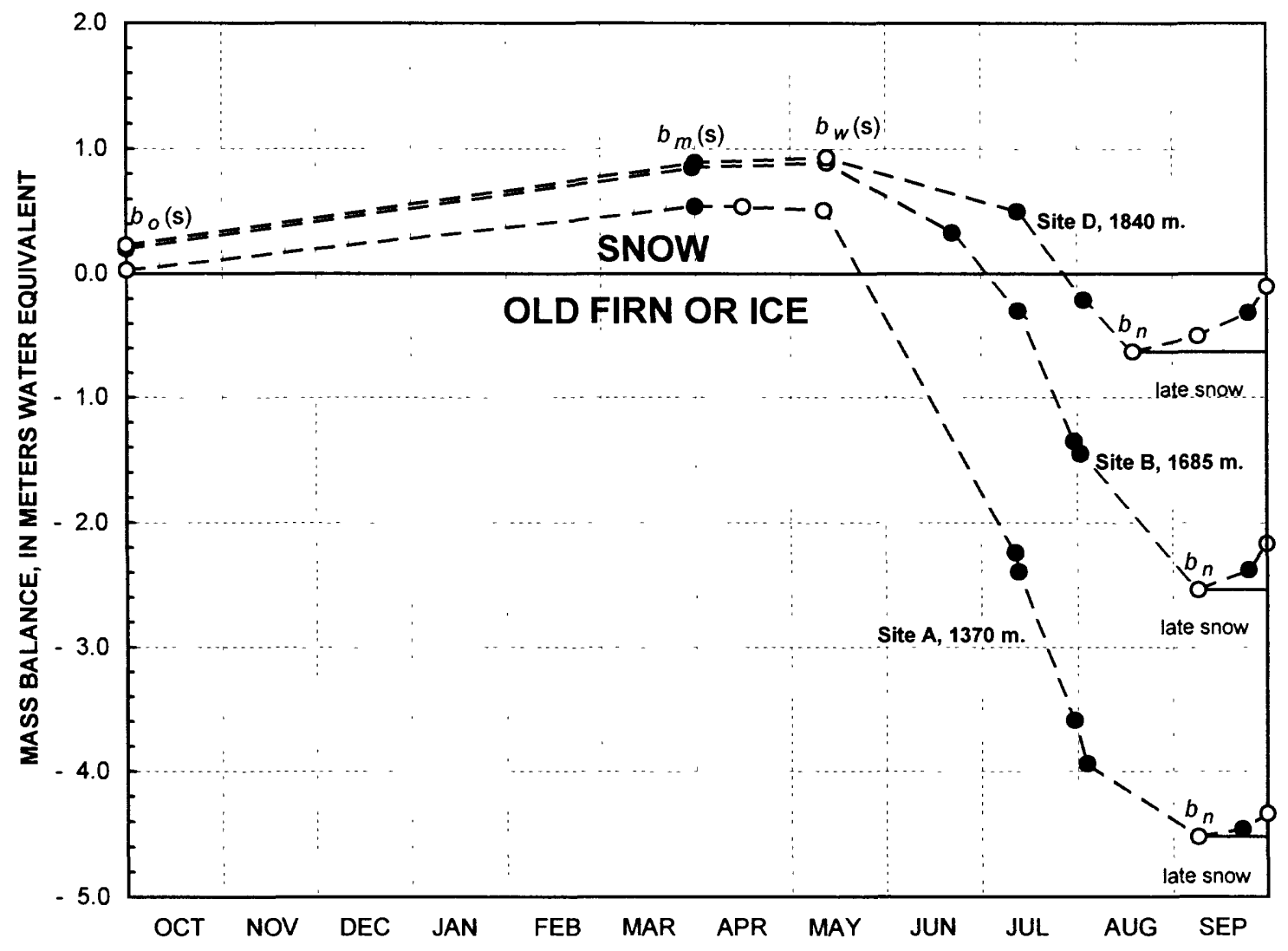

Figure 3. Time distribution of index-site mass balance for Gulkana Glacier, 1993 hydrologic year. (Solid circles are measured values; open circles are estimated values. Seasonal maximum balances occurred during mid-May. $b_{o}(\mathrm{~s})$, initial snow balance at site; $b_{m}(\mathrm{~s})$, measured winter snow balance at site; $b_{n}$, net balance at site; $b_{w}(\mathrm{~s})$, maximum winter snow balance at site.)

All locations are reported in local, metric coordinates, with the positive Y-axis approximately true north. Altitude is in meters above the National Geodetic Vertical Datum of 1929. Horizontal locations are defined in a local sea-level-scale network that may be converted to Universal Transverse Mercator (UTM) zone 6 coordinates North American Datum 1983 by:

$$
\begin{aligned}
\text { UTM Easting } & =k X_{L}+575,000 \mathrm{~m} \\
\text { UTM Northing } & =k Y_{L}+7,011,000 \mathrm{~m}
\end{aligned}
$$

where $X_{L}$ and $Y_{L}$ are local sea-level coordinates in meters and $k$ is the mean horizontal scale factor between the UTM plane and sea level. 


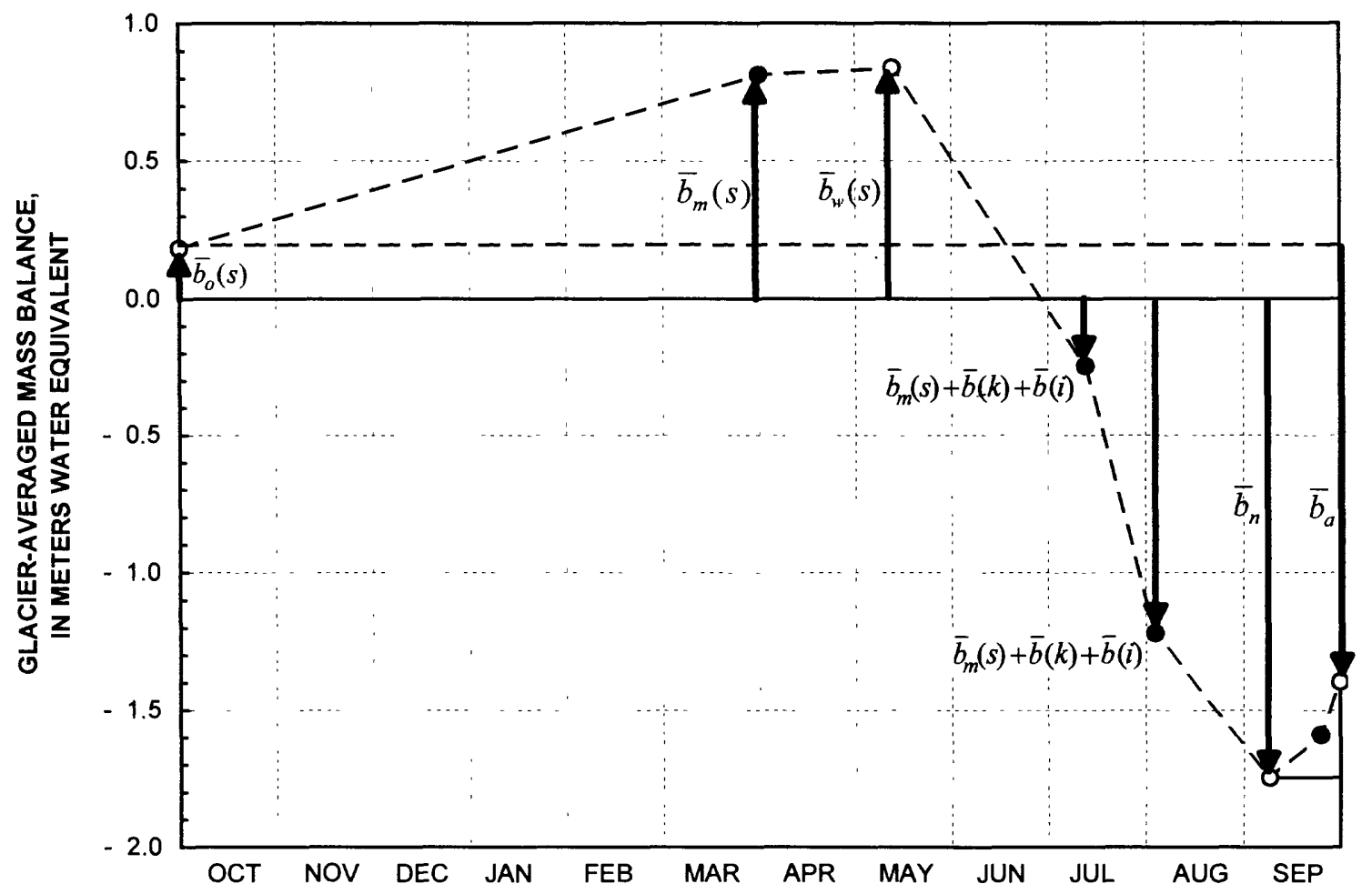

Figure 4. Time distribution of glacier-averaged mass balance of Gulkana Glacier, 1993 hydrologic year. (The initial balance, $b_{o}(\mathrm{~s})$, is the change in balance between the balance minimum that defines the beginning of the net balance year and the beginning of the hydrologic year (1 October). The measured winter snow balance, $b_{m}(\mathrm{~s})$, is the snow above the previous summer surface measured directly in the field near the time of the maximum snow balance, $b_{w}(\mathrm{~s})$. Solid circles are measured values; open circles are estimated values. A symbol with a bar over it indicates the average value over the whole glacier.)

The scale factor, $k$, at a point is a variable defined by:

$$
k=\frac{0.9996}{\sin \left(100+\frac{500,000-E}{100,000}\right)}
$$

where $E$ is the UTM Easting of the point and the trigonometric function is evaluated in grad.

The mean scale factor used in equations 1 and 2 to convert between the local sea-level system coordinates and UTM coordinates is the mean value of the nonlinear distribution of scale factors between the local sea-level system origin and an observation point. $E$ is approximated by the sum of the UTM Easting of the local system origin $(575,000 \mathrm{~m})$ and $X_{L}$. 


$$
\bar{k}=\frac{1}{X_{L}} \int_{575,000}^{575,000+X_{L}} k d E
$$

The mean scale factor is estimated using Simpson's 1/3 rule:

$$
\bar{k}=\frac{0.9996}{6}\left(\frac{1}{\sin \left(100+\frac{500,000-575,000}{100,000}\right)}+\frac{4}{\sin \left(100+\frac{500,000-575,000-1 / 2 X_{L}}{100,000}\right)}+\frac{1}{\sin \left(100+\frac{500,000-575,000-X_{L}}{100,000}\right)}\right)
$$

Equation 5 is accurate within about 0.1 part per million of equations from U.S. Departments of the Army and the Air Force (1951, specifically see page 219 and appendixes IV and V), and hence yields results accurate at the centimeter level.

\section{DATA COLLECTION}

The temporal distribution of the data used to analyze the 1993 mass balance is shown in table 2 .

\section{Field Visits}

Six field visits to the Gulkana Glacier basin between late September 1992 and late April 1994 (table 2) were used to collect the data necessary to evaluate the 1993 glacier mass balance, motion, and surface altitudes and to service and calibrate recorders. Generally the trips are timed to define the mass balance maximums and minimums, usually during a spring trip (March/April/May) and a late-summer/early-fall trip (September/October), respectively. In addition to measuring the nearmaximum balance, observations during the spring add redundancy to the fall measurements of the height of the summer surface on stakes and hence support a regular assessment of errors in balance calculations based on stake readings. A trip was also made during late July/early August 1993 to measure mass balance and glacier motion, and to resurvey glacier longitudinal profiles, cross profiles, and control points for analysis of long-term glacier volume change and in preparation for photogrammetric mapping.

\section{Recorded Variables}

Air temperature, precipitation-gage catch, and stream runoff data are recorded continuously. The recorded runoff data is meaningless after Phelan Creek freezes over in the early fall, and runoff must be estimated for the winter. The data sets are truncated to the hydrologic year. Periods of good recorder data are shown in table 2 .

\section{Air temperature}

Air temperature is recorded by an analog recorder at $1,480 \mathrm{~m}$ altitude on the eastern ice-cored moraine of Gulkana Glacier (weather station, fig. 1). The air temperature sensor, data reduction methodology, and data accuracy described for a similar gage at Wolverine Glacier (Mayo, March, and Trabant, 1992; Kennedy, 1995) are applicable to the Gulkana gage and data. Briefly, the sensor 


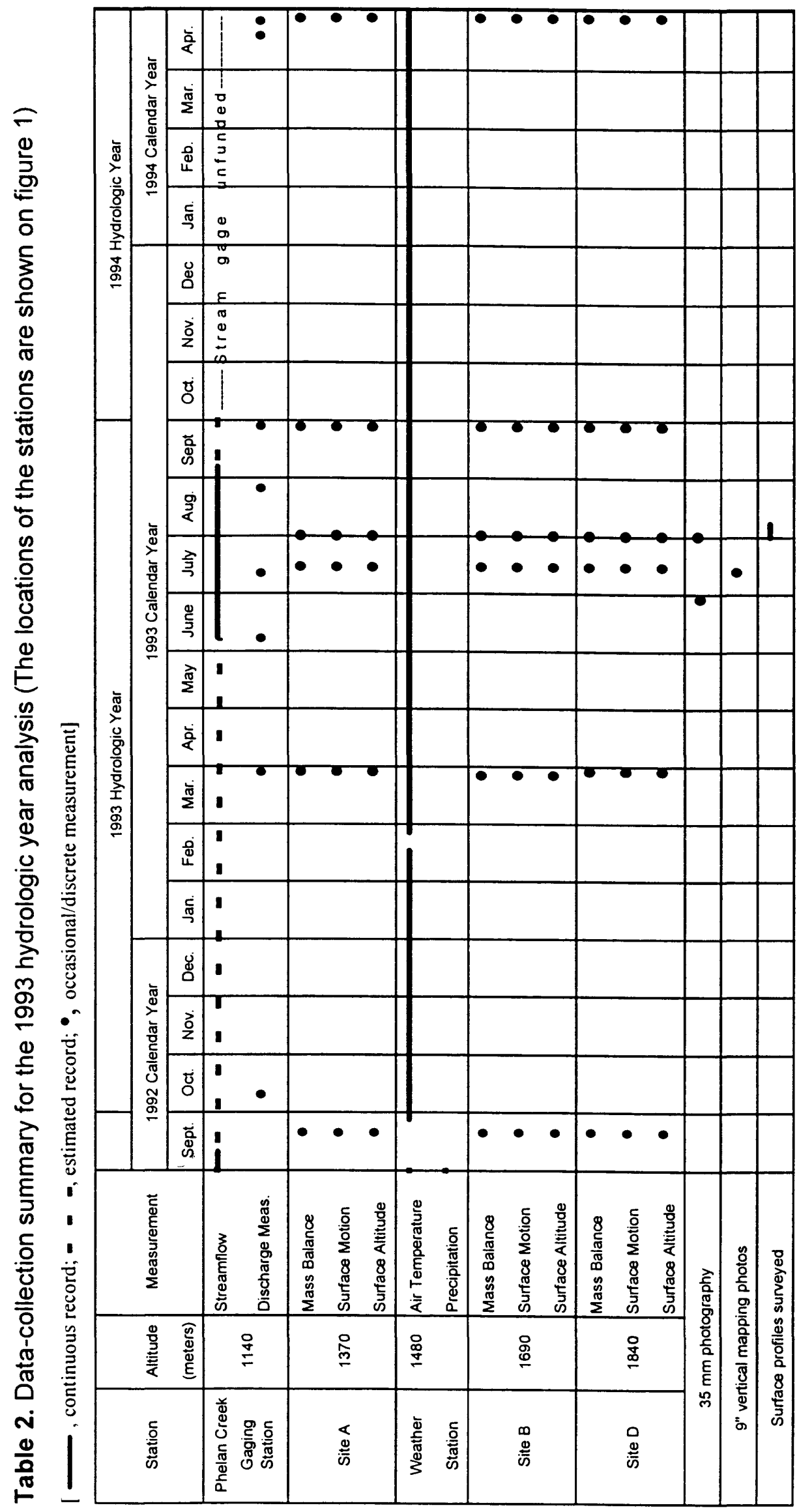


is a copper-finned, 20-x-300-mm, liquid-filled sensor designed for use in water. It has a slow response time in air that makes it good for determining daily average temperature, but poor for daily maximum and minimum temperatures which have not been extracted from the record. The sensor is housed in a small white shelter with slatted walls and an open bottom, $1.5-2.0 \mathrm{~m}$ above the ground. Snow accumulation is minimal at the site, so the height above the ground is not significantly reduced during the winter. A glass thermometer with one- or two-tenths graduations is used several times a year to make calibration measurements. The daily mean temperatures reported (fig. 5, table 3) have an accuracy of about $\pm 1.0^{\circ} \mathrm{C}$ (Mayo, March, and Trabant, 1992; Kennedy, 1995). Part of the 1993 record was lost because of recorder failure. Following the National Climatic Data Center convention (1996), monthly mean temperatures are calculated for months with nine or fewer missing daily values.

The annual average temperature for 1993 was $-3.5^{\circ} \mathrm{C}, 0.3$ standard deviation above the longterm average $(1968-91,1993-94)$ of $-3.9^{\circ} \mathrm{C}$.

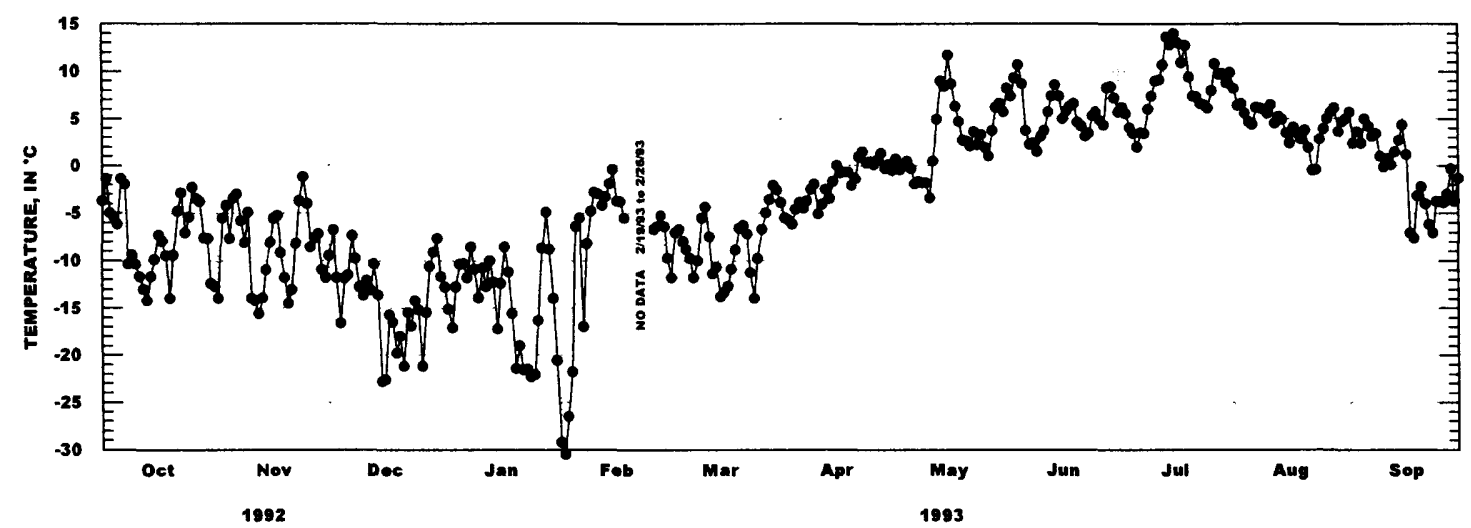

Figure 5. Daily mean air temperature recorded at 1,480 meters altitude in the Gulkana Glacier basin, 1993 hydrologic year.

\section{Precipitation catch}

Precipitation catch is recorded by an analog recorder connected to a storage-type precipitation gage at the weather station (fig. 1). The gage, data reduction methodology, and data accuracy have been described for a similar gage at Wolverine Glacier (Mayo, March, and Trabant, 1992; Kennedy, 1995). Briefly, the gage consists of a steel storage tank that tapers to a conical orifice, $0.305 \mathrm{~m}$ in diameter, $3 \mathrm{~m}$ above the ground. A modified Nipher shield (Warnick, 1953) is installed around the orifice to improve the catch efficiency during windy conditions.

Unfortunately, the precipitation-catch record for the 1993 hydrologic year shows evidence of fluid loss throughout the year. This could have been caused by either a fluid leak in the storage tank or by evaporation, which is normally prevented by an oil film on the surface of the stored antifreeze-water solution. Because the functioning of the gage returned to normal after replacing the oil film in the storage tank, the oil film was probably inadequate for all of the 1993 hydrologic year. Thus, the record is considered unreliable and it is not included in this report.

To estimate balance increments between measured values, which is necessary to determine the maximum winter balance, net balance, and annual balance (see description of temporal extrapolations under the "Balance at Specific Sites" section), the precipitation record from the nearest 
National Weather Service station, Paxson (station 50709704), has been used. Paxson is located at $823 \mathrm{~m}$ altitude, about $20 \mathrm{~km}$ south of the Gulkana weather station. The Paxson record is not included in this report but is available through the Utah Climate Center at http://climate.usu.edu/free/. The relation between the Gulkana and the Paxson precipitation has not been examined in detail; however, Paxson appears to be drier than the Gulkana weather station site, because it catches only about half as much precipitation annually (on the basis of data from 197584 and 1986-92), though this may also be caused by a reduced catch efficiency of the Paxson gage because it lacks a wind shield. The Pearson correlation coefficient between Gulkana and Paxson daily values of precipitation is 0.62 (1975-84 and 1986-92).

Table 3. Daily and monthly mean air temperature from the recording gage at 1,480 meters altitude, 1993 hydrologic year

[Values in degrees Celsius; $M$, insufficient or partial data. $M$ is appended to month average computed with 1-9 daily values missing. - - daily value missing]

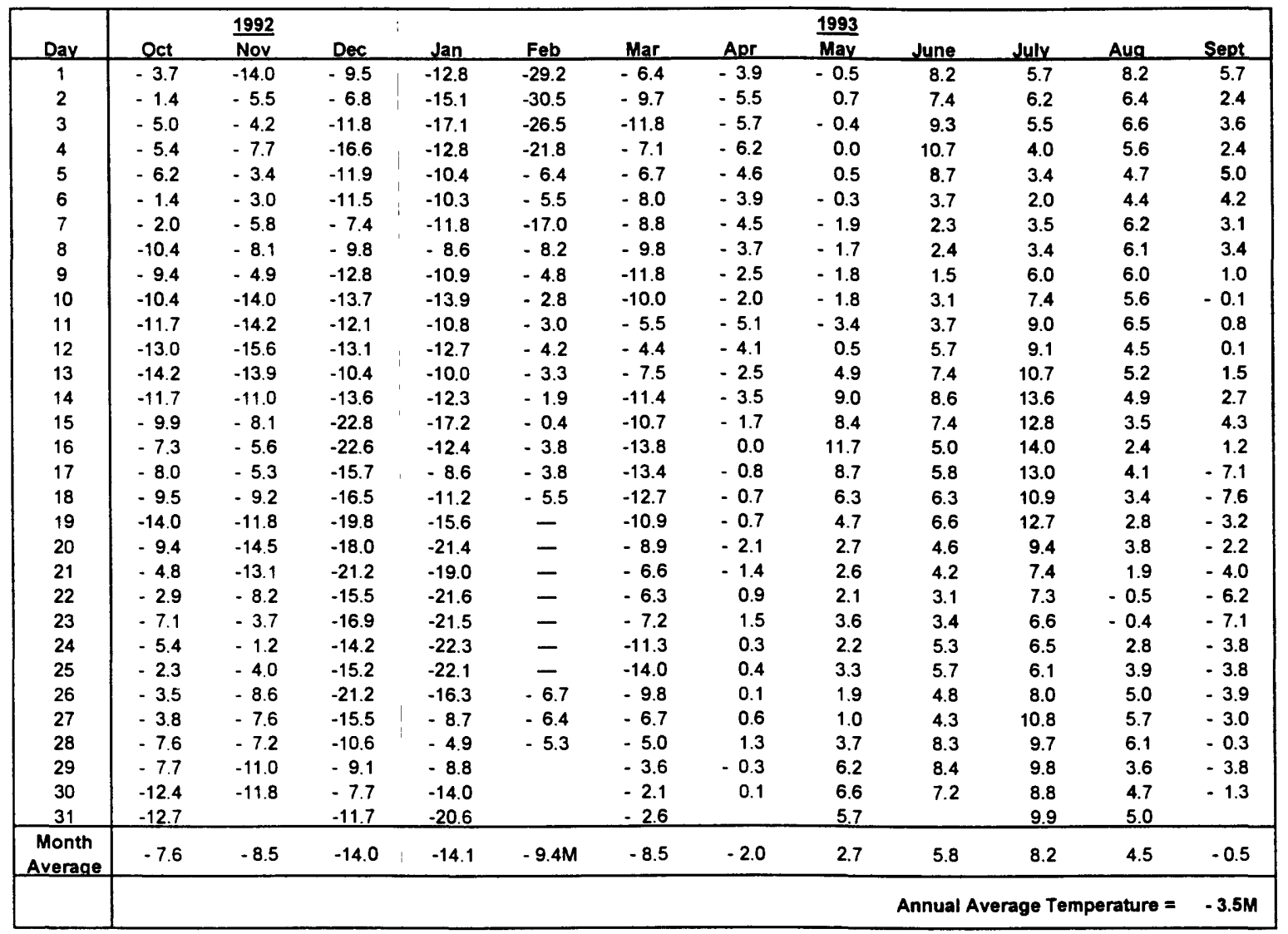

\section{Runoff}

The Phelan Creek stream-gaging station, USGS station 15478040, is part of the U.S. Geological Survey's network of 96 gaging stations in Alaska (Linn and others, 1994). Data collection and analysis are conducted by standard techniques developed by the Survey and daily values of discharge are reported along with those for the rest of Alaska in annual publications of the U.S. Geological Survey Water-Data Report series. The data for 1993 are reported by Linn and others (1994). 
The historical streamflow daily values for this station may be obtained online through the Internet at http://water.usgs.gov/swr.

The gaging station is located at $1,125 \mathrm{~m}$ altitude, about $1 \mathrm{~km}$ downstream from the present glacier terminus (fig. 1). The creek bed is composed of typical ground moraine material, poorly sorted gravel and small boulders. The channel is subject to frequent changes during high flows. Typical winter under-ice discharge is about $0.1 \mathrm{~m}^{3} / \mathrm{s}$; typical summer discharge is about $4-20 \mathrm{~m}^{3} / \mathrm{s}$; the period-of-record peak discharge is $65 \mathrm{~m}^{3} / \mathrm{s}$ (Linn and others, 1994). The typical minimum winter under-ice discharge is about $0.04 \mathrm{~m}^{3} / \mathrm{s}$, which is about three to four times the average contribution from the combined geothermal melt of the bed of the glacier and melting caused by the potential energy loss from the ice motion (see "Area-Averaged Balances" section). Due to the frequency of discharge measurements and the changeable nature of the creek bed, the published discharge record is rated as "poor," meaning that the records do not meet the criteria for a "fair" rating, which is defined as "about 95 percent of the daily discharges are within 15 percent of the true value" (Linn and others, 1994). This formal rating places no limit on the possible error. It is estimated that the standard error of the measured daily discharge values during the open-water season at Phelan Creek is about 10 percent (Richard Kemnitz, U.S. Geological Survey, oral commun., 1995).

The 1993 daily mean discharge data (Linn and others, 1994) were converted to runoff (fig. 6 , table 4) by dividing the discharge values by the basin area. The 1993 runoff from the basin was $1.996 \mathrm{~m}$, about 0.2 standard deviations above the period-of-record $(1967-78,1990-93)$ average.

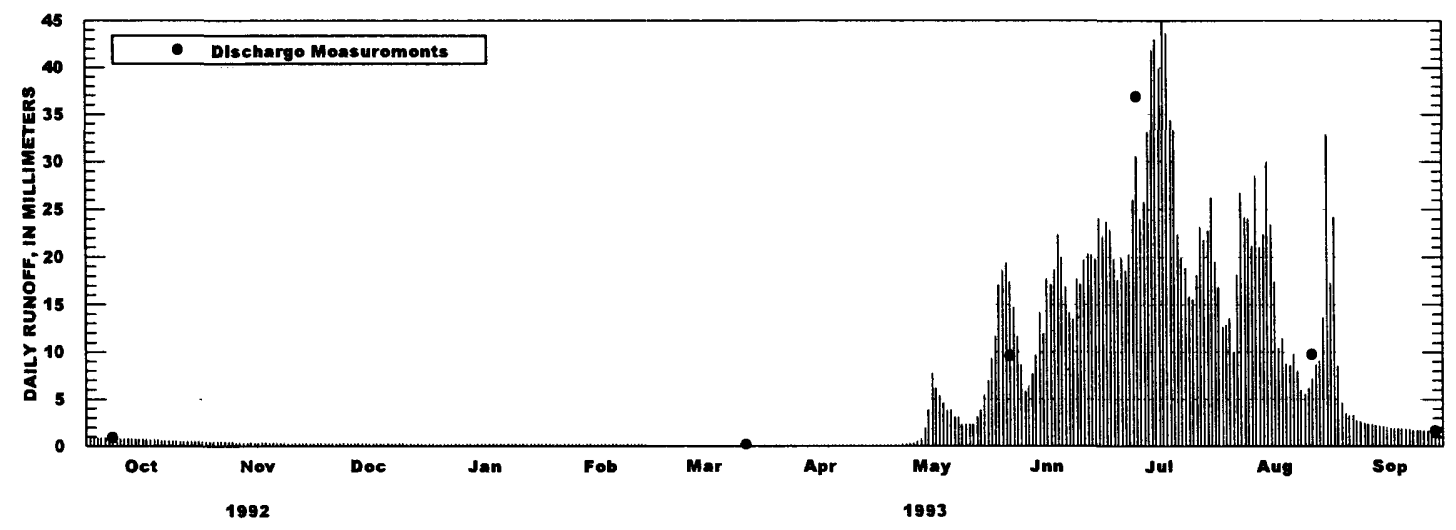

Figure 6. Daily runoff from Phelan Creek near Paxson (USGS stream-gaging station 15478040) (Linn and others, 1994) and discharge measurements used to calibrate the stage-discharge relationship, 1993 hydrologic year.

No continuous stage record is collected during the winter when Phelan Creek freezes over. Runoff values are estimated for the ice period on the basis of air temperature, precipitation, and winter discharge measurements (October 8, 1992; March 27, 1993; June 6, 1993; and September $28,1993)$. The relation between estimated daily runoff and the winter discharge measurements (converted to runoff rate) for the current year and for the entire period of record is shown in figure 7. Because the discharge measurements are so sparse in any one year, display of these measurements for the entire period of record is useful to help gage the possible error in these estimates. The range of measured values over the entire period of record suggests that the standard error in the estimates from October into early May is less than $\pm 0.2 \mathrm{~mm} / \mathrm{d}$, but then rapidly increases with 
the onset of the melt season in mid May to about $\pm 5 \mathrm{~mm} / \mathrm{d}$ by early June. The cumulative sum of winter estimated runoff represents about 15 percent of the annual runoff.

Table 4. Daily mean runoff from the Gulkana Glacier basin, 1993 hydrologic year, calculated from the published discharge of USGS stream-gaging station 15478040, Phelan Creek near Paxson, at 1,125 meters altitude and the basin area (Linn and others, 1994)

[Values in millimeters, averaged over the basin; () indicates value estimated (see text for explanation)]

\begin{tabular}{|c|c|c|c|c|c|c|c|c|c|c|c|c|c|}
\hline \multirow[b]{2}{*}{ Day } & \multicolumn{3}{|c|}{1992} & \multirow[b]{2}{*}{ Jan } & \multirow[b]{2}{*}{ Feb } & \multirow[b]{2}{*}{ Mar } & \multicolumn{3}{|c|}{$\underline{1993}$} & \multirow[b]{2}{*}{ July } & \multirow[b]{2}{*}{ Aug } & \multirow[b]{2}{*}{ Sept } & \multirow[b]{2}{*}{ Annual } \\
\hline & Oct & $\overline{\text { Nov }}$ & $D_{e c}$ & & & & Apr & $\overline{\text { May }}$ & June & & & & \\
\hline 1 & $(0.9)$ & ( 0.5$)$ & $(0.3)$ & $(0.2)$ & $(0.2)$ & $(0.2)$ & $(0.2)$ & $(0.2)$ & (9.3) & 22.1 & 16.7 & 24.2 & \\
\hline 2 & $(0.9)$ & $(0.5)$ & $(0.3)$ & $(0.2)$ & $(0.2)$ & $(0.2)$ & $(0.2)$ & $(0.2)$ & (11.6) & 23.7 & 12.6 & ( 8.5$)$ & \\
\hline 3 & $(0.9)$ & $(0.5)$ & $(0.3)$ & $(0.2)$ & $(0.2)$ & $(0.2)$ & $(0.2)$ & $(0.2)$ & $(17.0)$ & 22.8 & 12.9 & ( 4.7) & \\
\hline 4 & $(0.9)$ & $(0.5)$ & $(0.3)$ & $(0.2)$ & $(0.2)$ & $(0.2)$ & $(0.2)$ & $(0.2)$ & (18.6) & 19.6 & 13.6 & 3.5 & \\
\hline 5 & $(0.9)$ & $(0.5)$ & $(0.3)$ & $(0.2)$ & $(0.2)$ & $(0.2)$ & $(0.2)$ & $(0.2)$ & (19.4) & 17.6 & 10.0 & 3.3 & \\
\hline 6 & $(0.9)$ & $(0.5)$ & $(0.3)$ & $(0.2)$ & 0.2 & $(0.2)$ & $(0.2)$ & $(0.2)$ & (17.4) & 19.6 & 18.2 & 3.3 & \\
\hline 7 & $(0.9)$ & ( 0.5$)$ & $(0.3)$ & $(0.2)$ & $(0.2)$ & $(0.2)$ & $(0.2)$ & $(0.2)$ & (14.7) & 18.6 & 26.6 & 2.8 & \\
\hline 6 & $(0.9)$ & 0.5 & $(0.3)$ & $(0.2)$ & $(0.2)$ & $(0.2)$ & $(0.2)$ & $(0.2)$ & (11.6) & 20.3 & 24.2 & ( 2.6) & \\
\hline 9 & $(0.9)$ & $(0.5)$ & $(0.3)$ & $(0.2)$ & $(0.2)$ & $(0.2)$ & $(0.2)$ & $(0.2)$ & 8.7 & 26.0 & 24.1 & ( 2.5) & \\
\hline 10 & $(0.9)$ & ( 0.4$)$ & $(0.3)$ & $(0.2)$ & $(0.2)$ & $(0.2)$ & $(0.2)$ & $(0.3)$ & 5.8 & 30.5 & 21.1 & ( 2.4) & \\
\hline 11 & $(0.9)$ & $(0.4)$ & $(0.3)$ & $(0.2)$ & $(0.2)$ & $(0.2)$ & $(0.2)$ & $(0.4)$ & 6.4 & 24.1 & 28.5 & ( 2.3) & \\
\hline 12 & $(0.9)$ & $(0.4)$ & $(0.3)$ & $(0.2)$ & $(0.2)$ & $(0.2)$ & $(0.2)$ & $(0.5)$ & 7.7 & 25.8 & 21.0 & ( 2.3) & \\
\hline 13 & $(0.9)$ & $(0.4)$ & $(0.3)$ & $(0.2)$ & $(0.2)$ & $(0.2)$ & $(0.2)$ & $(0.8)$ & 9.7 & 33.1 & 22.3 & ( 2.2) & \\
\hline 14 & $(0.8)$ & $(0.4)$ & $(0.3)$ & $(0.2)$ & $(0.2)$ & $(0.2)$ & $(0.2)$ & ( 1.9) & 14.2 & 41.9 & 29.9 & $(2.1)$ & \\
\hline 15 & $(0.8)$ & $(0.4)$ & $(0.3)$ & $(0.2)$ & $(0.2)$ & $(0.2)$ & $(0.2)$ & ( 3.9$)$ & 11.9 & 43.1 & 23.4 & $(2.0)$ & \\
\hline 16 & $(0.8)$ & $(0.4)$ & $(0.3)$ & $(0.2)$ & $(0.2)$ & $(0.2)$ & $(0.2)$ & ( 7.7) & 17.7 & 39.9 & 17.4 & ( 1.9$)$ & \\
\hline 17 & $(0.8)$ & $(0.4)$ & $(0.3)$ & $(0.2)$ & $(0.2)$ & $(0.2)$ & $(0.2)$ & ( 6.2) & 17.1 & 44.9 & 10.5 & ( 1.9) & \\
\hline 18 & $(0.7)$ & $(0.4)$ & $(0.3)$ & $(0.2)$ & $(0.2)$ & $(0.2)$ & $(0.2)$ & ( 5.4$)$ & 18.7 & 43.7 & 11.5 & ( 1.9$)$ & \\
\hline 19 & $(0.7)$ & $(0.4)$ & $(0.3)$ & $(0.2)$ & $(0.2)$ & $(0.2)$ & $(0.2)$ & ( 4.7) & 22.3 & 34.4 & 8.6 & ( 1.9$)$ & \\
\hline 20 & $(0.7)$ & $(0.4)$ & $(0.3)$ & $(0.2)$ & $(0.2)$ & $(0.2)$ & $(0.2)$ & ( 3.9$)$ & 19.9 & 33.3 & 8.6 & ( 1.6) & \\
\hline 21 & $(0.6)$ & $(0.4)$ & $(0.3)$ & $(0.2)$ & $(0.2)$ & $(0.2)$ & $(0.2)$ & ( 3.9 ) & 16.9 & 22.4 & 9.6 & $(1.8)$ & \\
\hline 22 & $(0.6)$ & $(0.4)$ & $(0.3)$ & $(0.2)$ & $(0.2)$ & $(0.2)$ & $(0.2)$ & ( 3.1$)$ & 14.1 & 19.9 & 8.0 & (1.7) & \\
\hline 23 & $(0.6)$ & $(0.4)$ & $(0.3)$ & $(0.2)$ & $(0.2)$ & $(0.2)$ & $(0.2)$ & (3.1) & 13.5 & 16.8 & 6.0 & ( 1.7$)$ & \\
\hline 24 & $(0.6)$ & $(0.3)$ & $(0.3)$ & $(0.2)$ & $(0.2)$ & $(0.2)$ & $(0.2)$ & (2.3) & 17.7 & 15.9 & 5.5 & ( 1.7$)$ & \\
\hline 25 & $(0.6)$ & ( 0.3$)$ & $(0.3)$ & $(0.2)$ & $(0.2)$ & $(0.2)$ & $(0.2)$ & (2.3) & 17.2 & 15.6 & 6.2 & ( 1.7) & \\
\hline 26 & $(0.5)$ & $(0.3)$ & $(0.2)$ & $(0.2)$ & $(0.2)$ & $(0.2)$ & $(0.2)$ & ( 2.3) & 19.7 & 16.1 & 7.1 & ( 1.6$)$ & \\
\hline 27 & $(0.5)$ & $(0.3)$ & $(0.2)$ & $(0.2)$ & $(0.2)$ & 0.2 & $(0.2)$ & (2.3) & 20.4 & 23.2 & 8.7 & ( 1.6) & \\
\hline 28 & $(0.5)$ & $(0.3)$ & $(0.2)$ & $(0.2)$ & $(0.2)$ & $(0.2)$ & $(0.2)$ & ( 3.1$)$ & 20.2 & 21.8 & 9.1 & ( 1.6$)$ & \\
\hline 29 & $(0.5)$ & $(0.3)$ & $(0.2)$ & $(0.2)$ & & $(0.2)$ & $(0.2)$ & ( 3.9) & 19.8 & 22.8 & 13.6 & $(1.6)$ & \\
\hline 30 & $(0.5)$ & $(0.3)$ & $(0.2)$ & $(0.2)$ & & $(0.2)$ & $(0.2)$ & ( 5.4) & 24.1 & 26.3 & 32.9 & $(1.6)$ & \\
\hline 31 & $(0.5)$ & & $(0.2)$ & $(0.2)$ & & $(0.2)$ & & $(7.0)$ & & 19.5 & 17.3 & & \\
\hline Sum & (23.1) & (11.8) & $(9.1)$ & $(7.1)$ & ( 6.4) & ( 4.7$)$ & (4.5) & (75.9) & (463.2) & 809.4 & 485.9 & (94.6) & $\mid$\begin{tabular}{|l|}
$1,995.8$ \\
\end{tabular} \\
\hline Sum of Measured Values & 0.0 & 0.0 & 0.0 & 0.0 & 0.0 & 0.0 & 0.0 & 0.0 & 343.6 & 809.4 & 485.9 & 37.1 & 1675.9 \\
\hline Sum of Estimatec & $(23.1)$ & (11.8) & (9.1) & $(7.1)$ & $(6.4)$ & $(4.7)$ & ( 4.5) & (75.9) & (119.6) & $(0.0)$ & $(0.0)$ & (57.6) & (319.9) \\
\hline$\%$ Mea & $0 \%$ & $0 \%$ & $0 \%$ & $0 \%$ & $0 \%$ & $0 \%$ & $0 \%$ & $0 \%$ & $74 \%$ & $100 \%$ & $100 \%$ & $39 \%$ & $84 \%$ \\
\hline
\end{tabular}

\section{Photography}

Nine-inch, color, vertical, derial photographs were acquired on July 11, 1993, at a scale of $1: 36,000$ ( 1 inch=3,000 feet) covering the entire basin for the purpose of preparing a new topographic map of the Gulkana Glacier basin. Additionally, parts of the Gulkana Glacier basin were photographed from low altitude and the ground with a hand-held 35-mm camera during the 1993 HY (table 2). 


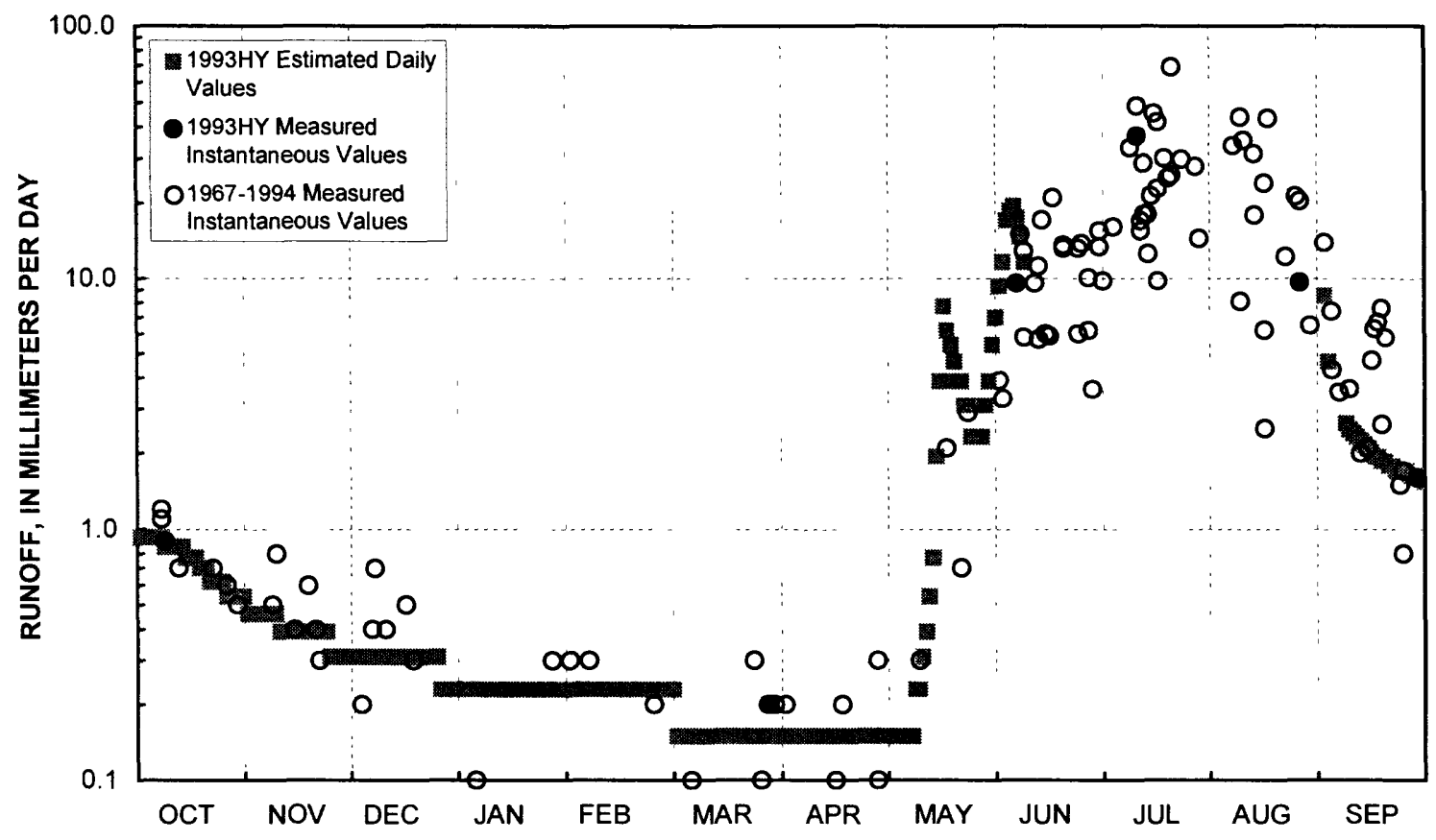

Figure 7. Estimated daily runoff from Phelan Creek near Paxson for the 1993 hydrologic year (USGS stream-gaging station 15478040) (Linn and others, 1994) with measured values for both the 1993 hydrologic year and the entire period of record (1967-94).

\section{MASS BALANCE EVALUATION}

\section{Mass Balance Measurement Errors}

Mass balance analysis seeks relatively small net changes in a system where accumulation and ablation are large. Because of this, even small measurement errors can significantly change the result, including the sign of the result. Furthermore, mass balance measurement errors are difficult to treat analytically because of problems inherent in sampling and extrapolation. Uncertainties in the mass balance determination at index sites (the sampling points) arise from a combination of the uncertainties in determining stake measurements, snow and firn densities, snow depths, and internal accumulation. Indeed, many errors must be estimated because there are an insufficient number of independent samples to warrant error analysis; for example, seldom are there more than two balance-motion stakes at an index site or more than one snow-density pit. Uncertain at this time is the error introduced by extrapolating from a few index-site values to glacier-wide and basin values. An independent assessment of long-term glacier volume change by means of profile surveying and photogrammetric mapping is in progress to assess this error and, if necessary, revise the algorithm for extrapolating glacier-wide balance from index-site values. Error estimates are included in the tabular data in this report. 


\section{Balance at Specific Sites}

Measured winter snow balance, maximum winter snow balance, net mass balance, and the annual mass balance are determined at each index site using largely traditional methods (Østrem and Brugman, 1991; and Østrem and Stanley, 1969); the stake, pit, probing, coring, and meteorological data are shown in tables 5, 6, and 7 and figure 3 .

Though mass balance measurement locations are often referred to as "points" on a glacier, they are treated as small areas $25-75 \mathrm{~m}$ in radius, centered on each index site, over which samples are taken and the balance averaged. The area chosen is large enough and enough samples are taken in the area so that when a quantity, such as snow depth, is averaged over the area, the error caused by the glacier-surface and summer-surface roughness (up to several meters on some glaciers) is small. Likewise, stake readings are taken to be the intersection of the average, "visually smoothed" glacier surface (out to $25-75 \mathrm{~m}$ ) with the stake and not just where the snow, ice, or firn is right at the stake.

One departure from traditional methods is surveying of the stake and glacier-surface geometry and subsequent analysis to correct for the lean and bending which commonly occurs after the initial near-vertical installation of the stakes. These corrections affect the stake position for motion (see "Ice Motion Measurement and Errors" section) and the height on the stake of the glacier surface, $b^{\prime}$ (table 5), that is used for some balance determinations. It is assumed that the bottom of the stake is the most likely point on the stake to be "locked" into the glacier and not move relative to the glacier. The stake's geometry above the glacier surface is surveyed, assumptions about the stake's geometry (lean, bend, or bow) below the glacier surface are made, and the position of the bottom of the stake is calculated. The height of the point on the glacier surface directly above the stake bottom is then calculated using the surveyed geometry of the glacier surface and is used as a corrected $b^{\prime}$ as if the stake were vertical. The local glacier surface slope is measured during every field visit for use in this calculation. The stake $b^{\prime}$ corrections typically change the balance readings by about $5 \mathrm{~cm}$, but occasionally up to $0.5 \mathrm{~m}$.

Another departure from traditional methods is the way multiple measurements of the height of a summer surface on a stake are used to reduce balance errors. For example, snow depth and stake height of the snow surface are usually measured during the fall and again during the winter or spring, resulting in two measurements of the stake height of the previous summer surface. If the measurements were made in the accumulation zone, a third measurement may be made the following fall by subtracting the snow depth and new firn depth from the stake height of the glacier surface. Because of measurement error, these successive measurements of the height of a summer surface on the stake are usually different; however, barring stake slip or firn compaction (in the accumulation zone), the height of the summer surface on the stake should not have changed. The interpretation that the differing stake measurements are the result of measurement error is reinforced by the fact that multiple measurements vary randomly, sometimes increasing and sometimes decreasing. For this analysis, the multiple measurements are combined using a weighted average. The weight for each measurement is proportional to the number of observations that went into the measurement. For instance, a measurement that is the average of 20 snow-depth probings is given twice the weight of a measurement with 10 snow-depth probings. The weighted average stake height of the summer surface is used for all calculations of balance relative to that summer surface. 
Table 5. Stake readings, snow depths, and snow density data for sites A, B, and D on Gulkana Glacier, September 1992 - April 1994

$[\mathrm{mm} / \mathrm{dd} / \mathrm{yy}$, month/day/year; stake name: the first two digits represent the year the stake was installed; letter (A, B, D) represents the site on the glacier (fig. 1); a number following the letter is used to differentiate multiple stakes installed at the same site in one year. LSnow (late snow), snow on top of the current year's summer surface, occurs only after the summer surface has formed. Obs. (observed) $b^{\prime}$, the average height on the stake of the glacier surface within a 50-meter radius of the stake. $b^{*}$, stake height of surveyed point on the stake near $b^{\prime}$. $b^{* *}$, surveyed $b^{*}$ corrected for stake lean, bend, or bow. $b^{*}-b^{* *}$, value to be applied to correct $b^{\prime}$ for stake lean, bend or bow. Total stake slip, cumulative distance the stake bottom has moved into the glacier since installed; it is generally assumed that the stake bottom is fixed in the glacier. Best $b^{\prime}$, observed $b^{\prime}$ corrected for stake lean, bend, bow, and/or slippage or, in other words, the calculated height of the glacier surface directly above the stake bottom (i.e. as if the stake were vertical). Stake $d(\mathrm{~s})$, snow depth as determined from the best $b^{\prime}$ and previous or subsequent determinations of the stake height of the summer surface. Pit $d(\mathrm{~s})$, snow depth measured in snow pit. McCall $d(\mathrm{~s})$, snow depth measured with a McCall snow sampler, a small-diameter sampler used to core the entire snowpack. Probe $d(s)$, snow depth measured by probing to the summer surface with a metal rod. Mean $d(\mathrm{~s})$, average snow depth. s.e. $d(\mathrm{~s})$, standard error of snow depth. $n$, number of snow depth samples. Snow density, measured in snow pit, by McCall snow sampler, or estimated and mean density. m, meter; $\mathrm{kg} / \mathrm{L}$, kilograms per liter]

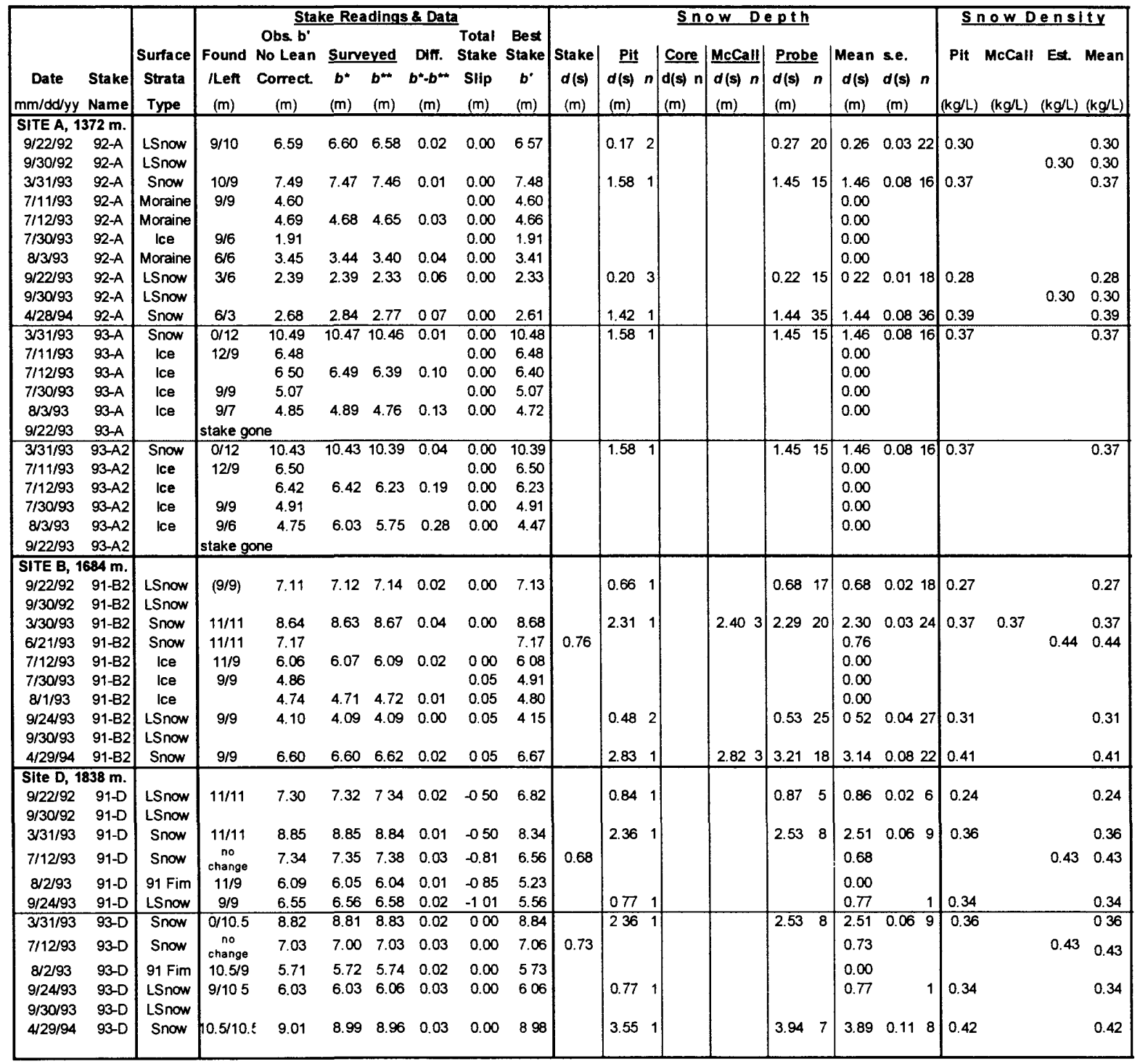


Table 6. Snow temperature, firn thickness, and firn density data for sites $A, B$, and $D$ on Gulkana Glacier, September 1992 - April 1994

$\left[\mathrm{mm} / \mathrm{dd} / \mathrm{yy}\right.$, month/day/year; summer surface temperature, observed with dial $\left( \pm 1.0^{\circ} \mathrm{C}\right)$ or digital $\left( \pm 0.1^{\circ} \mathrm{C}\right)$ thermometer in snow pit or core sample. Est., estimated from previous measurements. Heights are above the stake bottom. Depths are measured from the glacier surface. Initial values are those at the beginning of the hydrologic year. Obs., observed values on a date, generally the difference between the best stake $b^{\prime}$ and multiple snow or firn depth observations. Mean (stake heights), average stake heights of a stratigraphic surface (summer surface) observed on different dates. Mean depth, average of all pit, McCall, and probing depths for a given date. s.e., standard error; $n$, number of observations. $\mathrm{ss}_{1}$, first glacier summer surface down from the glacier surface (this is typically a bare ice surface in the ablation zone and a firn surface in the accumulation zone); $\mathrm{ss}_{2}$, second glacier summer surface down from the glacier surface (this is typically a firn surface; multiple summer surfaces only occur in the accumulation zone of the glacier). Diff., the difference between the observed value and the mean value for that date, a good unbiased indication of the error in the stake height and snow and firn depth data at a site, commonly $0.05-0.15 \mathrm{~meter} ; \mathrm{m}, \mathrm{meter} ; \mathrm{kg} / \mathrm{L}$, kilogram per liter]

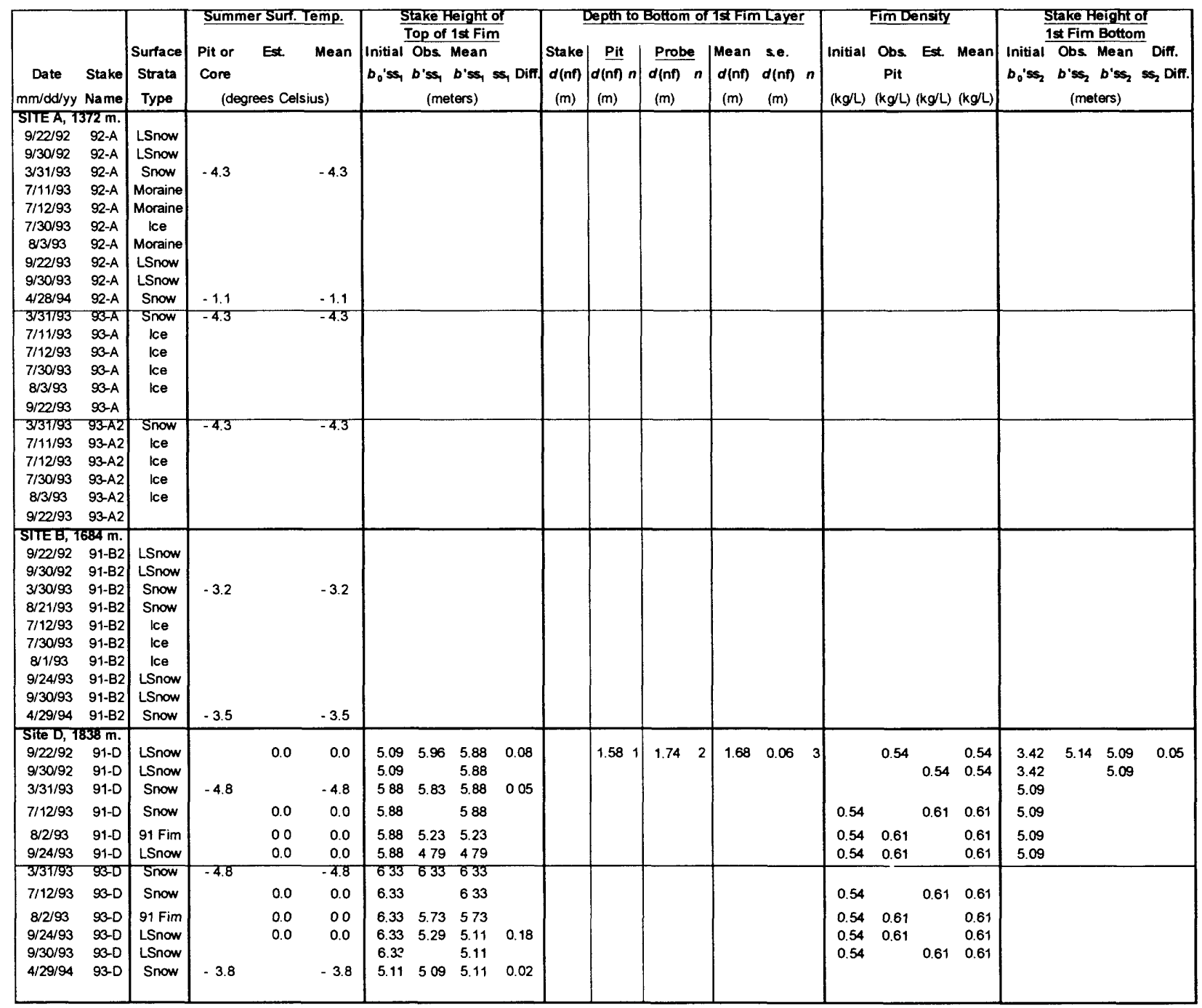


Table 7. Ice data and mass balance calculations for sites A, B, and D on Gulkana Glacier, September 1992 - April 1994

$\left[\mathrm{mm} / \mathrm{dd} / \mathrm{yy}\right.$, month/day/year; $b_{0}(\mathrm{~s})$, initial snow balance; $b_{0}(\mathrm{i})$, initial ice balance; $b(\mathrm{~s})$, snow balance; $b(\mathrm{ls})$, late snow balance; $b(\mathrm{f})$, firn balance; $b(\mathrm{k})$, internal accumulation; $b(\mathrm{i})$, ice balance; $b_{n}$, net balance; $b_{a}$, annual balance; me, meters water equivalent (see Mayo and others (1972) for detailed explanation of this terminology)]

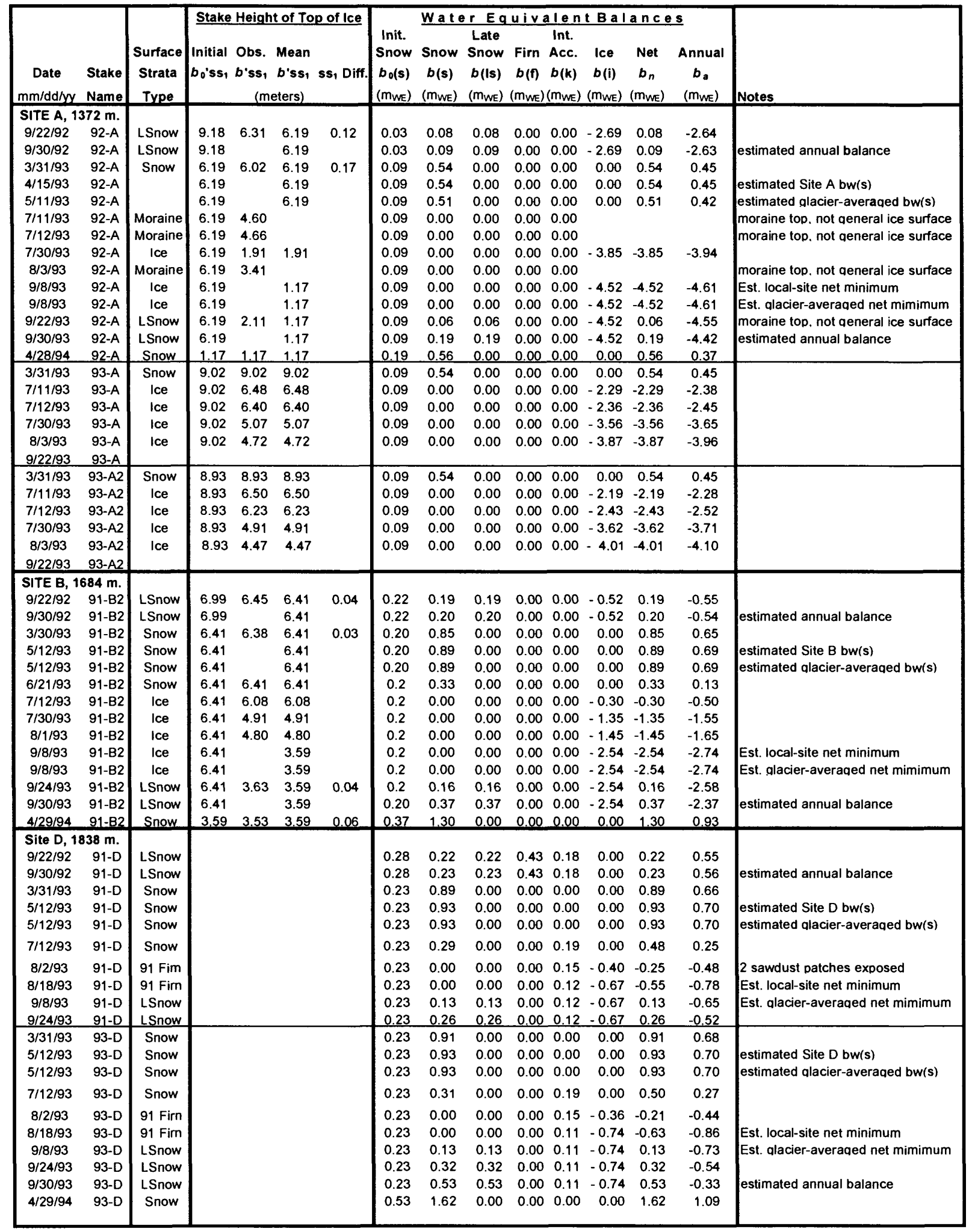

18 Mass Balance, Meteorological, Ice Motion, Surface Altitude, and Runoff Data at Gulkana Glacier, Alaska, 1993 Balance Year 
Temporal extrapolations between measurements are necessary to estimate index-site balances such as the maximum winter balance, net balance, and annual balance. The extrapolations are made by a simple linear model that relates the air temperature recorded at the Gulkana weather station and precipitation-gage catch from Paxson to the mass balance at each index site. The temperature is lapsed from the recorder altitude to each of the index-site altitudes using the wet-adiabatic lapse rate of $-0.66^{\circ} \mathrm{C}$ per $100 \mathrm{~m}$ altitude increase. The model estimates glacier ablation at the rate of about $3.5-5 \mathrm{~mm}$ water equivalent per degree Celsius above $0^{\circ} \mathrm{C}$ per day, when the surface is snow, and twice that when the surface is ice or old firn. This range of values agrees with those common in the literature (Braithwaite and Olesen, 1985; Braithwaite and Olesen, 1993). Glacier accumulation is estimated by the model to be about 1.5 to 4.0 times the precipitation-gage catch when the lapsed temperature at the site is below $1.8^{\circ} \mathrm{C}$. The melt (ablation) rate and the precipitationcatch multipliers are not fixed. Values are chosen for each measurement period so that the calculated balances agree with the measured balances for each measurement period at each index site. Thus the model serves only to distribute the measured balance at each index site over each measurement interval.

\section{Area-Averaged Balances}

The index-site balance values are combined using weighting factors to yield glacier-wide index values that approximate the average balances for the glacier area:

$$
b=0.196\left(b_{A}\right)+0.225\left(b_{B}\right)+0.579\left(b_{D}\right)+b_{a}(\mathrm{j})
$$

where $b$ is the glacier-averaged balance, $b_{A}, b_{B}$, and $b_{D}$ are measured index-site balance values, and $b_{a}(\mathrm{j})$ is glacier-averaged internal ablation. The weighting factors $(0.196$ for site $\mathrm{A}, 0.225$ for site $\mathrm{B}$, and 0.579 for site $\mathrm{D}$ ) are derived by splitting the glacier into three sub-areas (index regions) at altitudes midway between the index sites (table 1). The percentage of total glacier area in each index region is the weighting factor for the index site within that region. For this method to be valid, the index site balance value should equal the average balance in the index region.

This weighted index-site method was tested by applying it to the 1966 and 1967 measured winter-snow balance and annual firn-and-ice balance data (Meier and others, 1971; Tangborn and others, 1977), and comparing the results with the published balances for those years. The 1966 and 1967 balances serve as ground truth because they are based on detailed surface-balance mapping. The results of the comparison (March and Trabant, 1996) showed that the weighted index-site values were within the estimated errors of the mapped balances, and suggest that glacier-averaged balance values determined using the weighted index-site method have an error of $\pm 0.2 \mathrm{~m}$.

The weighted index-site method and its error are considered preliminary until further verification and adjustment from an independent assessment of the long-term, glacier mass balance change is obtained from a photogrammetric or surveyed volume change of the entire glacier.

It should be emphasized that, because of the time- and space-transgressive nature of glacier balance, the $b_{A}, b_{B}$, and $b_{D}$ values used to calculate a glacier average balance such as the net balance may not be the same as the site net balances because when the glacier-averaged balance reaches its minimum, there may already be snow accumulated at sites $D$ and $B$ (see fig. 3 ). 
The glacier-averaged internal ablation, $b_{a}(\mathrm{j})$, is calculated by combining three internal and subglacial energy sources: the geothermal heat at the bed of the glacier, the potential energy loss from ice motion, and the potential energy loss from water flowing through the glacier and along the bed of the glacier (Mayo, 1992):

$$
\text { average geothermal heat flow }=1.2 \frac{\mu \mathrm{cal}}{\mathrm{cm}^{2}-\mathrm{sec}}
$$

yields $0.005 \mathrm{~m} / \mathrm{yr}$ water equivalent ice melt

Internal ablation caused by the potential energy loss by ice motion is estimated by assuming an equilibrium situation in which the glacier annually transports the long-term, average firn balance, $b_{a}(\mathrm{f})=m$, from the accumulation zone to replace the annual ice loss from the ablation zone:

$$
\begin{aligned}
& \Delta U_{I}=m g \Delta Z \\
& =\left(\frac{b_{a}(f) \mathrm{gm} / \mathrm{cm}^{2} \mathrm{yr}}{1000 \mathrm{gm} / \mathrm{kg}}\right)\left(9.8 \mathrm{~m} / \mathrm{s}^{2}\right)(-447 \mathrm{~m}) \\
& =-1.65 \text { joules } / \mathrm{cm}^{2} \mathrm{yr} \\
& \text { yields } 0.005 \mathrm{~m} / \mathrm{yr} \text { water equivalent ice melt }
\end{aligned}
$$

where $\Delta U_{I}$ is the glacier-averaged change in potential energy per unit area per year from ice motion; $m$ is the mass in kilograms; $\mathrm{g}$ is the acceleration of gravity; $\Delta Z$ is the change in altitude in meters.

Internal ablation caused by the potential energy loss by water flow through and beneath the glacier is estimated by assuming that 95 percent of the basin runoff descends from an average altitude a little below the ELA to the glacier terminus:

$$
\begin{aligned}
\Delta U_{W} & =m g \Delta Z \\
& =\left(\frac{0.95 r_{a} \mathrm{gm} / \mathrm{cm}^{2} \mathrm{yr}}{1000 \mathrm{gm} / \mathrm{kg}}\right)\left(\frac{31.6 \mathrm{~km}^{2}}{19.32 \mathrm{~km}^{2}}\right)\left(9.8 \mathrm{~m} / \mathrm{s}^{2}\right)\left[Z_{\text {Terminus }}-\left(Z_{\mathrm{ELA}}-100\right) \text { meters }\right] \\
& =-18.75 \mathrm{joules} / \mathrm{cm}^{2} \mathrm{yr} \\
& \text { yields } 0.06 \mathrm{~m} / \mathrm{yr} \text { water equivalent ice melt }
\end{aligned}
$$

where $\Delta U_{W}$ is the glacier-averaged change in potential energy per unit area per year from water flow; $r_{a}$ is the 1993 annual basin runoff, $1.996 \mathrm{~m} ; Z_{\text {Terminus }}$ is the 1993 altitude of the terminus, 1,161 meters; $Z_{\mathrm{ELA}}$ is the 1993 altitude of the ELA, $1,878 \mathrm{~m}$.

For the period 1967-78, Mayo (1986) estimated that 15 percent of the Gulkana basin runoff was from alpine, non-glacier area and 85 percent from glacier area. It is estimated that two-thirds of the alpine runoff ( 10 percent of the basin runoff) ultimately flows under the glacier causing glacier melt; hence the 95 percent used in equation 9. 


\section{Weather in 1992-93}

The 1993 net balance year began August 18, 1992, when the entire glacier was covered by fresh snow that did not melt. The seasonal runoff recession began in late August 1992. The last day of open-water stage at the stream-gaging station was recorded on September 9, 1992. As is typical, no surface melt occurred on the glacier between October 1 and mid-April. The lowest daily mean winter air temperature was $-30.5^{\circ} \mathrm{C}$ on February 2, 1993. Winter (mid-September to mid-May) temperature averaged $-8.6^{\circ} \mathrm{C}$, nearly normal. The 1993 glacier-averaged mass balance maximum occurred May 10-11, although glacier melt began low on the glacier in mid-April (fig. 3). The maximum daily mean summer temperature was $14.0^{\circ} \mathrm{C}$ on July 16 . Summer (mid-May to mid-September) temperature averaged $5.5^{\circ} \mathrm{C}, 1^{\circ} \mathrm{C}$ above normal. The final glacier-averaged mass balance minimum occurred about September 8, 1993 though snow accumulation had started at Site D in mid-August (fig. 3); the seasonal runoff recession began after August 31, 1993, when the season's last precipitation-caused runoff peak ended. The total runoff for the 1993 water year was 5 percent above the mean for the 16-year period of record (1967-78 and 1990-93 hydrologic years).

\section{Measured and Maximum Winter Snow Balances ${ }^{2}$}

The measured winter snow balance, $b_{m}(\mathrm{~s})$, is the snow balance measured to the previous summer surface during late winter or spring (Mayo, Meier, and Tangborn, 1972). It was $0.81 \mathrm{~m}$ on March 31, 1993 (table 8). This value was derived from the weighted index-site method and the March field visit data (tables 5, 6, and 7).

The maximum winter snow balance, $b_{w}(\mathrm{~s})$, is the maximum snow mass during the balance year and may occur either before or after the measured winter snow balance (Mayo, Meier, and Tangborn, 1972). It generally occurs after the time of the measured winter snow balance at Gulkana Glacier. The balance change between the time of the measured winter snow balance and the time of the glacier-averaged, maximum winter snow balance is estimated for each index site by the simple balance model discussed in the earlier section of this report, "Balance at Specific Sites." The normal time of the maximum winter snow balance tends to be a time of low balance flux at Gulkana Glacier. The 1993 maximum winter snow balance of $0.84 \mathrm{~m}$ (table 8) was reached on May 10, 1993 (almost a month after melt had begun low on the glacier, figure 3), and remained until May 11, 1993, when melt spread from the lower glacier to the middle and upper glacier.

\section{Net Balance}

Net balance is the change in snow, firn, and ice storage between times of minimum glacieraveraged mass (Mayo, Meier, and Tangborn, 1972). The net balance, $b_{n}$, at each index site is calculated directly from stake, pit, and probing data (table 8). Because of the time-transgressive nature

\footnotetext{
2 Mayo, Meier, and Tangborn (1972) define three "winter" balance values in the stratigraphic system: the measured winter snow balance, $b_{m}(\mathrm{~s})$, the maximum winter snow balance, $b_{w}(\mathrm{~s})$, and the winter balance, $b_{w}$. The World Glacier Monitoring Service (WGMS) publishes a "winter" balance that is not clearly identified as any of these and may vary from glacier to glacier. The measured winter snow balance, $b_{m}(\mathrm{~s})$, is probably the most common "winter" balance value reported by WGMS.
} 
Table 8. Site and area-integrated balance quantities for Gulkana Glacier and Gulkana Glacier Basin, 1993 hydrologic year

[m, meters; mm/dd/yy, month/day/year; $\mathrm{km}^{2}$, square kilometers; ${ }^{\circ} \mathrm{C}$, degrees Celsius]

\begin{tabular}{|c|c|c|c|}
\hline Parameter & Site, glacier average, or sub-parameter & Data & Units \\
\hline \multirow[t]{3}{*}{ Index site weighting factors } & Site A & 0.196 & \\
\hline & Site B & 0.225 & \\
\hline & Site D & 0.579 & \\
\hline \multirow[t]{4}{*}{$b_{0}(s)$, initial snow balance } & Site A & 0.09 & (m) \\
\hline & Site B & 0.20 & $(\mathrm{~m})$ \\
\hline & Site D & 0.23 & (m) \\
\hline & Glacier average & 0.20 & $(\mathrm{~m})$ \\
\hline \multirow[t]{5}{*}{$b_{m}(s)$, measured winter snow balance } & Date of measurement & $3 / 31 / 93$ & $(\mathrm{~mm} / \mathrm{dd} / \mathrm{yy})$ \\
\hline & Site A & 0.54 & $(\mathrm{~m})$ \\
\hline & Site B & 0.85 & (m) \\
\hline & Site D & 0.89 & (m) \\
\hline & Glacier average & 0.81 & $(\mathrm{~m})$ \\
\hline \multirow{5}{*}{$b_{w}(s)$, maximum winter snow balance } & Date of maximum & $05 / 10 / 93-05 / 11 / 93$ & $(\mathrm{~mm} / \mathrm{dd} / \mathrm{yy})$ \\
\hline & Site A & 0.51 & $(m)$ \\
\hline & Site B & 0.89 & (m) \\
\hline & Site D & 0.93 & (m) \\
\hline & Glacier average & 0.84 & $(\mathrm{~m})$ \\
\hline \multirow[t]{4}{*}{$b_{n l}$, late net balance increment } & Site A & 0.00 & $(\mathrm{~m})$ \\
\hline & Site B & 0.00 & $(m)$ \\
\hline & Site $D$ & 0.13 & (m) \\
\hline & Glacier average & 0.08 & (m) \\
\hline \multirow{4}{*}{$b_{1}(l s)$, final late snow balance } & Site A & 0.19 & (m) \\
\hline & Site B & 0.37 & (m) \\
\hline & Site D & 0.53 & (m) \\
\hline & Glacier average & 0.43 & (m) \\
\hline \multirow{4}{*}{$b_{a}(f)$, new firm balance } & Site A & 0.00 & $(m)$ \\
\hline & Site B & 0.00 & (m) \\
\hline & Site D & 0.00 & (m) \\
\hline & Glacier average & 0.00 & $(\mathrm{~m})$ \\
\hline \multirow[t]{4}{*}{$b_{a}(k)$, internal accumulation } & Site A & 0.00 & (m) \\
\hline & Site B & 0.00 & (m) \\
\hline & Site D & 0.11 & (m) \\
\hline & Glacier average & 0.06 & $(\mathrm{~m})$ \\
\hline \multirow[t]{4}{*}{$b_{a}(i)$, old firn and ice balance } & Site A & -4.52 & (m) \\
\hline & Site B & -2.54 & (m) \\
\hline & Site D & -0.71 & (m) \\
\hline & Glacier average & -1.87 & $(\mathrm{~m})$ \\
\hline \multirow[t]{4}{*}{$b_{a}(0)$, internal ablation (glacier averaged) } & From geothermal heat flux & -0.005 & (m) \\
\hline & From potential energy loss from ice motion & -0.005 & (m) \\
\hline & From potential energy loss from water flow & -0.056 & (m) \\
\hline & Total & -0.07 & (m) \\
\hline \multirow[t]{6}{*}{$b_{n}$, net balance } & Start of net balance year for glacier average & $8 / 18 / 92$ & $(\mathrm{~mm} / \mathrm{dd} / \mathrm{yy})$ \\
\hline & End of net balance year for glacier average & 9/8/93 & $(\mathrm{mm} / \mathrm{dd} / \mathrm{yy})$ \\
\hline & Site A & -4.52 & (m) \\
\hline & Site B & -2.54 & (m) \\
\hline & Site D & -0.47 & (m) \\
\hline & Glacier average (includes $b_{a}(j)$ ) & -1.80 & $(\mathrm{~m})$ \\
\hline \multirow[t]{4}{*}{$b_{a}$, annual balance } & Site $A$ & -4.42 & (m) \\
\hline & Site B & -2.37 & (m) \\
\hline & Site D & -0.30 & (m) \\
\hline & Glacier average (includes $b_{a}(j)$ ) & -1.64 & $(\mathrm{~m})$ \\
\hline ELA & & 1,871 & $(\mathrm{~m})$ \\
\hline Accumulation area & & 8.47 & $\left(\mathrm{~km}^{2}\right)$ \\
\hline Ablation area & & 10.85 & $\left(\mathrm{~km}^{2}\right)$ \\
\hline AAR & & 0.44 & \\
\hline Annual average air temperature & 1480 meter weather station & -3.5 & $\left({ }^{\circ} \mathrm{C}\right)$ \\
\hline Annual total precipitation gage catch & 1480 meter weather station & recorder failed & (m) \\
\hline Calculated annual precipitation & Basin average & 0.731 & (m) \\
\hline Annual basin runoff & 1125 meter stream gage & 1.996 & $(m)$ \\
\hline
\end{tabular}

22 Mass Balance, Meteorological, Ice Motion, Surface Altitude, and Runoff Data at Gulkana Glacier, Alaska, 1993 Balance Year 
of balance, the net balance at one site may not represent the same time period as the net balance at another site. Therefore, the simple linear balance model, described above, is run to determine the glacier-averaged net balance based on calculated site balances for the same time period. The net balance year ends almost a month earlier at site D than it does at sites A and B (fig. 3). The estimated balance at site D for September 8, 1993, that was used for calculating the glacier-averaged net balance, is also shown in figure 3 . These calculated site balances differ from the tabulated net balances (table 8 ) by a small increment which is the initial and late net balance increments, $b_{n 0}$ and $b_{n l}$ (in table $8, b_{n 0}$ is zero for 1993 and does not appear in the table). Field measurements made near the end of the balance year are checked by and combined with measurements during the next balance year before final values are assigned (tables 5, 6, and 7). The glacier-averaged net balance includes the additional balance term, internal ablation, which is not included in the net balances at individual sites. The 1993 net balance year began on about August 18, 1992, and ended on about September 8, 1993; the net balance was $-1.80 \mathrm{~m}$ (table 8).

\section{Summer Balance}

The summer balance, $b_{s}$, was not defined by Mayo, Meier, and Tangborn (1972); the definition of the United Nations Educational, Scientific, and Cultural Organization/ International Association of Scientific Hydrology (UNESCO/IASH) (1970), which says the summer balance is the algebraic difference between the winter balance and the net balance, $b_{n}$, is followed. The UNESCO/IASH definition of winter balance, which corresponds to the $b_{w}(\mathrm{~s})$ term from Mayo, Meier, and Tangborn (1972), is used:

$$
b_{s=} b_{n}-b_{w}(\mathrm{~s})=-2.64 \mathrm{~m}
$$

\section{Annual Mass Balance}

Annual mass balance is the change in snow, firn, and ice storage between the beginning (October 1, 1992) and end (September 30, 1993) of the hydrologic year. Evaluation of the 1993 annual balance required estimating two adjustment quantities: the initial snow balance at each index site, $b_{0}(\mathrm{~s})$ (table 8), at the beginning of the hydrologic year and the final late snow balance at each index site, $b_{l}(\mathrm{ls})$ (table 8), at the end of the hydrologic year (Mayo, Meier, and Tangborn (1972). These quantities were estimated using the simple linear balance model discussed earlier along with stake, air temperature, and precipitation data. The 1993 annual balance at each index site, $b_{a}$, is derived from the net balance and adjustment quantities: $b_{a}=b_{n}-b_{0}(\mathrm{~s})+b_{l}(\mathrm{ls})$ (table 7). The index-site annual balances are combined using the weighted index-site method, with the addition of the internal ablation, to yield the 1993 annual balance of $-1.64 \mathrm{~m}$ (table 8).

\section{Accumulation Area Ratio and Equilibrium Line Altitude}

The accumulation area ratio (AAR) is the accumulation area of the glacier divided by the total area of the glacier. The accumulation area is the area of the glacier which undergoes net mass gain and includes areas of firn accumulation, superimposed ice, and areas where internal accumulation exceeds old firn loss. The glacier surface area used for defining the $1993 \mathrm{AAR}, 19.3 \mathrm{~km}^{2}$, is the value determined for reporting the 1967 balance data (Tangborn and others, 1977) and has not been updated. The lower glacier has thinned and retreated slightly from 1960 to 1973 and 1983 (Mayo 
and Trabant, 1986). Since 1983, the lower glacier has continued to thin about $1 \mathrm{~m} / \mathrm{yr}$ and has probably been accompanied by minor terminus retreat. Updating the glacier area is not expected to significantly alter the AAR. The 1993 AAR was 0.44 .

The equilibrium line altitude (ELA) is the average altitude where the net mass balance is zero. Sometimes the ELA will correspond to the highest transient snow or firn line reached in the melt season (the line where snow ablation equals snow accumulation), but commonly the ELA is lower on the glacier because of internal accumulation in old firn or the presence of superimposed ice. The ELA seldom crosses a glacier along a single altitude contour. At Gulkana Glacier, the ELA can be extremely complicated and would require well-timed vertical or high-angle oblique aerial photography to define it over the whole glacier. Obtaining this kind of photography near the time of formation of the ELA on a consistent basis year after year is impractical. Additionally, ELA detection on aerial or satellite imagery can be difficult when the visual contrast is low between snow and old firn or between glacier ice and superimposed ice and may be impossible when the ELA occurs down-glacier from the snow line because of internal accumulation in old firn. Therefore, the ELA is calculated by linear interpolation from the balance-altitude curve of the three index sites. The 1993 ELA for Gulkana Glacier was determined to be $1,871 \mathrm{~m}$ (table 8).

\section{ICE MOTION MEASUREMENT AND ERRORS}

Surface ice displacements near the fixed index sites are measured during each field visit by optical surveying of balance-motion stakes. The stakes are installed about one year's flow displacement upstream from each index site. Replacement stakes are installed every year or two. Thus, the stakes are kept within one year's displacement of the index site (typically less than $80 \mathrm{~m}$ ) to maximize the year-to-year comparability of the motion data. The optical surveying techniques have been described by Mayo and others (1979) and Mayo and Trabant (1982). Reported velocities (table 9) are the average velocities derived from the linear displacement of the bottom of the stake divided by the measurement period. The bottom of the stake is used for the velocity determination because stakes installed vertically are usually found later to be leaning and on rare occasions bent or bowed. (The terms "bent" and "bend" are used to describe stakes with a sharp bend which are treated analytically as two line segments. The term "bow" is used to describe stakes with a gradual bend which are treated analytically as if part of the stake is an arc.) Movement of the bottom of the stake is believed to be the most representative of the motion of the glacier ice near the surface. Hence, reported stake motion data have been corrected for changes in stake geometry.

The position of the bottom of the stake is determined by surveying two points on each stake (one at the glacier surface and the other 1 or $2 \mathrm{~m}$ higher on the stake) and calculating the location of the stake bottom using a lean (linear), bend, or bowed stake geometry. In the long history of field observations at Gulkana Glacier, it has been rare to find melted-out stakes bent or bowed, so a "lean" geometry is generally assumed unless the stake is severely tilted. Occasionally, when a stake is severely tilted, it is partly excavated to determine if it is bent or bowed, and where. Some of the stakes tend to straighten as they are dug up and the snow creep load is removed, a sign that the stake was elastically bowed. Three-meter sections of the $2.5-\mathrm{cm}$ diameter thinwall EMT conduit used for stakes can be elastically bowed about 13 grads (an arc radius of about $15 \mathrm{~m}$ ) in the lab. When a bend or bow does occur, it is generally at or above the most recent summer surface. 


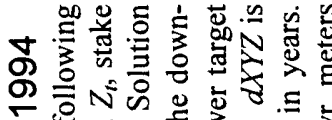

든

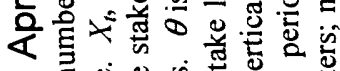

人

ภิ

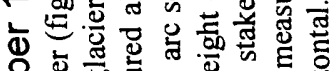

है:

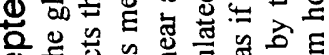

め)

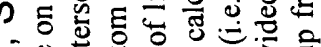

की.

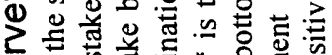

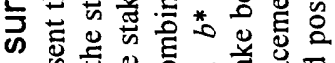

ত্

은 혼 究

응

हตी

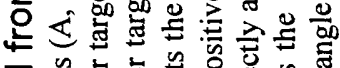

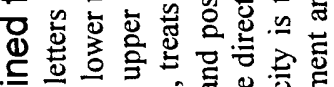

हैं

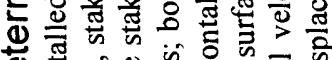

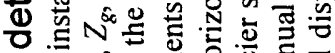

든

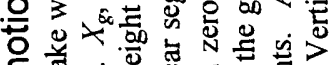

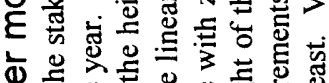

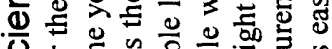

西

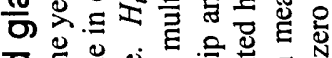

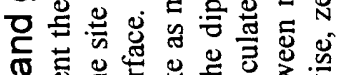

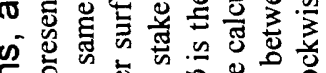

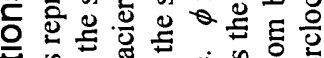
Uิ

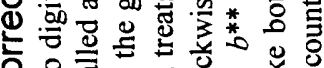

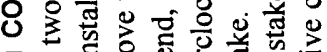

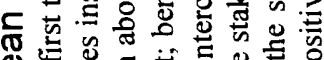
论

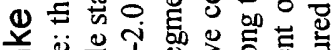

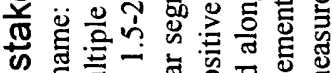

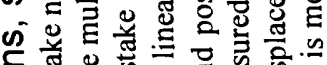

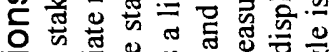

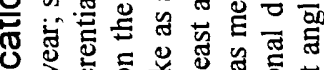

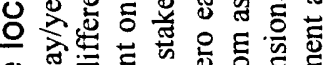

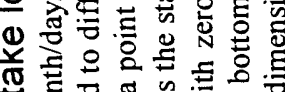

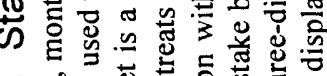
の

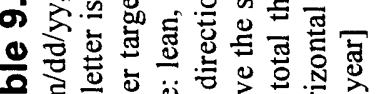

\begin{tabular}{|c|c|c|c|c|c|c|}
\hline ț & 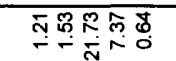 & 守 & 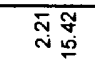 & 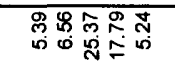 & 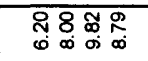 & 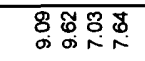 \\
\hline 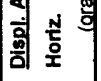 & 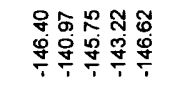 & 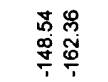 & 帝 & 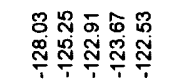 & 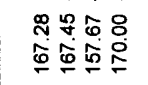 & 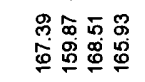 \\
\hline$\frac{\mathrm{g}}{\mathrm{g}}$ & 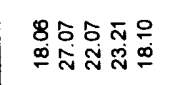 & 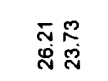 & 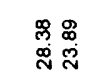 & 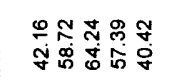 & 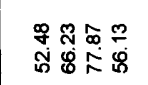 & 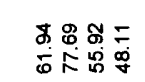 \\
\hline ฟुछ हु & 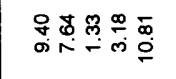 & 88 & $\bar{\infty}_{\infty}^{\ddagger}$ & 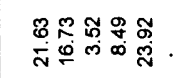 & 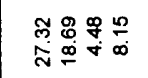 & 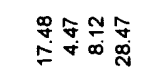 \\
\hline & 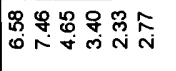 & 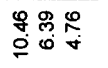 & 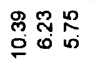 & 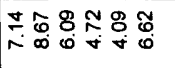 & 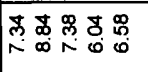 & $\begin{array}{ll}88.888 \\
\infty\end{array}$ \\
\hline : & 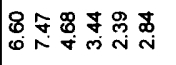 & 氕 & 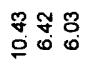 & 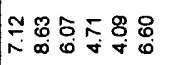 & 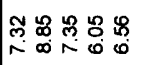 & ד \\
\hline N & 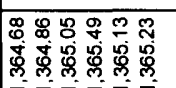 & 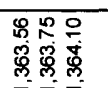 & 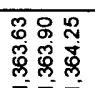 & 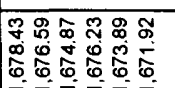 & 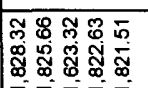 & 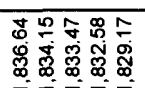 \\
\hline : & 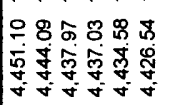 & 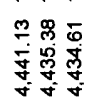 & 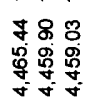 & 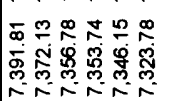 & 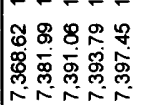 & 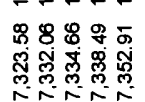 \\
\hline$x$ & 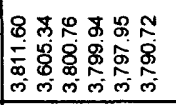 & 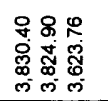 & 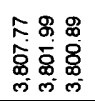 & 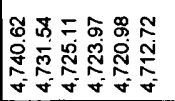 & 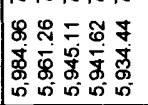 & 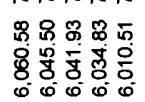 \\
\hline & 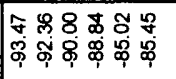 & 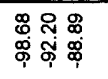 & 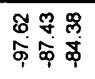 & 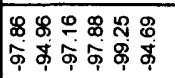 & 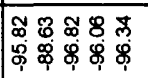 & 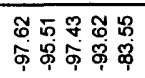 \\
\hline 羊。 & 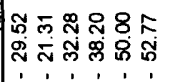 & 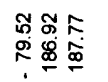 & 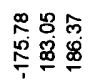 & 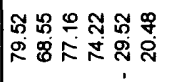 & 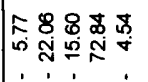 & 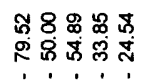 \\
\hline & & & & & & 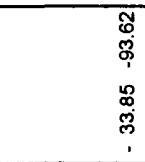 \\
\hline & 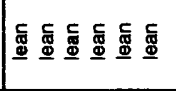 & 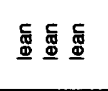 & 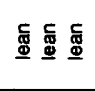 & 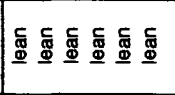 & 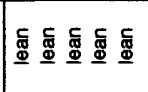 & 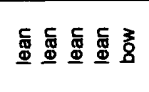 \\
\hline 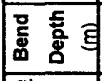 & & & & & & $\stackrel{8}{\circ}$ \\
\hline- & | & 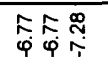 & 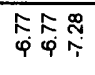 & 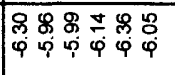 & 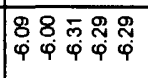 & 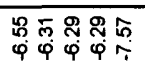 \\
\hline 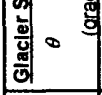 & 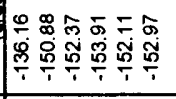 & 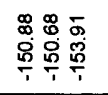 & 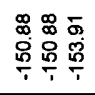 & 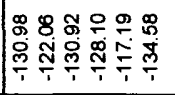 & 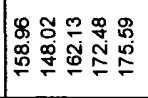 & 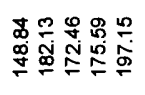 \\
\hline 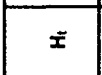 & 8. & 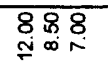 & 8:88 & $\begin{array}{l}8.88 \\
0\end{array}$ & 8 & $\begin{array}{l}08880 \\
0 \% \\
0\end{array}$ \\
\hline & 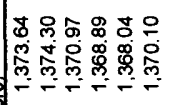 & 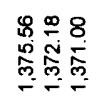 & 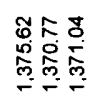 & 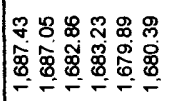 & 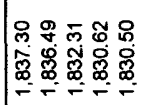 & 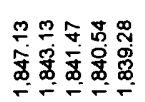 \\
\hline . & 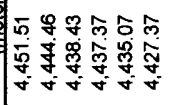 & 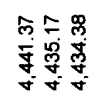 & 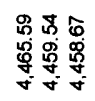 & 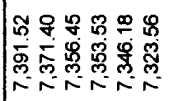 & 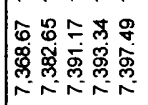 & 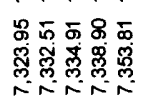 \\
\hline $\bar{x}$ & 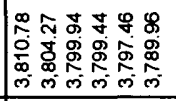 & 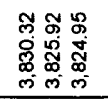 & 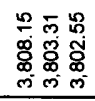 & 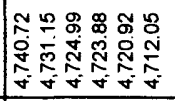 & 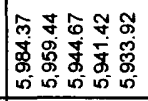 & 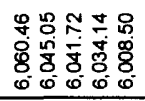 \\
\hline I $N$ & 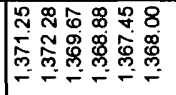 & 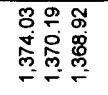 & 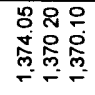 & 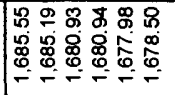 & 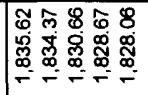 & 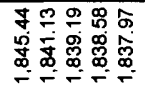 \\
\hline 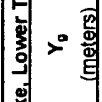 & 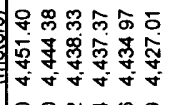 & 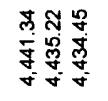 & 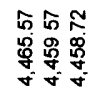 & 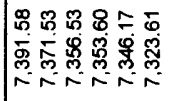 & 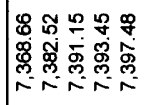 & 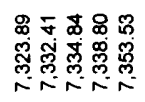 \\
\hline : & 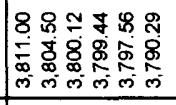 & 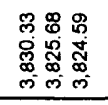 & 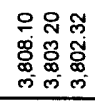 & 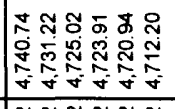 & 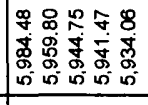 & 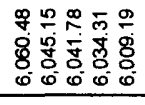 \\
\hline 递戛 & 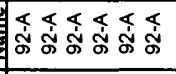 & 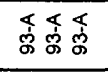 & 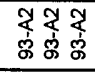 & 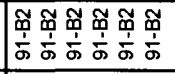 & 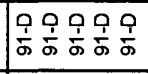 & 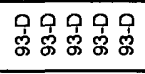 \\
\hline- & 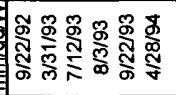 & 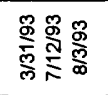 & 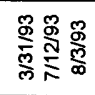 & 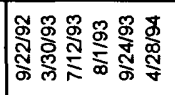 & 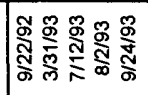 & 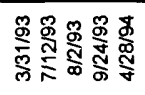 \\
\hline & & & & $8 \sigma^{\prime}$ & & \\
\hline
\end{tabular}


Determining, measuring, and correcting the stake geometry is an important process. It is, however, imprecise. Stake connectors, which join 3-m sections to make taller stakes, allow stake tilt of about $\pm 1.5 \mathrm{grad}$ at connectors. This translates into a horizontal position change of $0.15 \mathrm{~m}$ at the bottom of the typical stake that extends $6 \mathrm{~m}$ into the glacier. The uncertainty in determining the stake's geometry (lean, bend, or bow) is estimated to double this error, resulting in a total error in the horizontal of $\pm 0.3 \mathrm{~m}$ from geometric corrections. Measuring this error would require digging up a statistically significant number of stakes, an unreasonable task. The bottom of the stake $\left(X_{s} Y_{s}\right.$ in table 9) is typically offset horizontally $0.3-1.5 \mathrm{~m}$ from the surveyed target on the stake at the glacier surface $\left(X_{g} Y_{g}\right.$ in table 9$)$. Therefore, the stake geometry corrections are significant and would typically lead to motion errors of 5-20 percent in the Gulkana data if not corrected.

Location uncertainty is largely a result of the survey control net errors (GPS for horizontal and optical surveying for vertical) and resection survey errors. Resection surveys are conducted by surveying four or five backsight targets, instead of the minimum of three backsight targets, to allow error evaluation. The net and resection errors combined yield position errors of about $\pm 0.15 \mathrm{~m}$ in the horizontal and $\pm 0.05 \mathrm{~m}$ in the vertical. Additionally, glacier motion errors include the error in assuming a stake geometry and extrapolating from surveyed points on the stake to the bottom of the stake. The error of extrapolating to the bottom of the stake is estimated to be $\pm 0.15 \mathrm{~m}$, giving a total horizontal error for stake bottom positions of $\pm 0.2 \mathrm{~m}$. Vertical errors are significantly less, about $\pm 0.05 \mathrm{~m}$. Hence, reported displacements have errors of about $0.3 \mathrm{~m}$.

\section{GLACIER SURFACE ALTITUDE MEASUREMENT AND ERRORS}

The glacier surface altitude at each index site is measured during each field visit (tables 1011). At least three points on the glacier surface in the vicinity of the index site are optically surveyed. One of the points is placed as closely as possible to the index site. The mathematical plane defined by the three surveyed points is calculated as an approximation to the local glacier surface. The altitude of this plane at the fixed horizontal position of the index site is calculated to determine the index site altitude (Mayo and Trabant, 1982).

Surveyed glacier-surface points typically have an altitude uncertainty of about $\pm 0.05 \mathrm{~m}$; this uncertainty is a combination of survey net errors. Additionally there is the possibility that the locations used to define the plane of the glacier surface are not representative of the average glacier surface and hence extrapolating along this plane to the index site introduces further error. The glacier surface orientation and slope determinations have a small random variability that is used to assess the magnitude of this error. While this error is site specific, depending largely on the local surface roughness of the glacier, an average glacier-surface-slope error of $0.5 \mathrm{grad}$ was applied to the distance between the closest surveyed point and the index site. This error combined with the surveying error yields an average error of $\pm 0.15 \mathrm{~m}$ for the index-site altitudes. Index-site errors are calculated separately for each measurement and are included in table 10. 


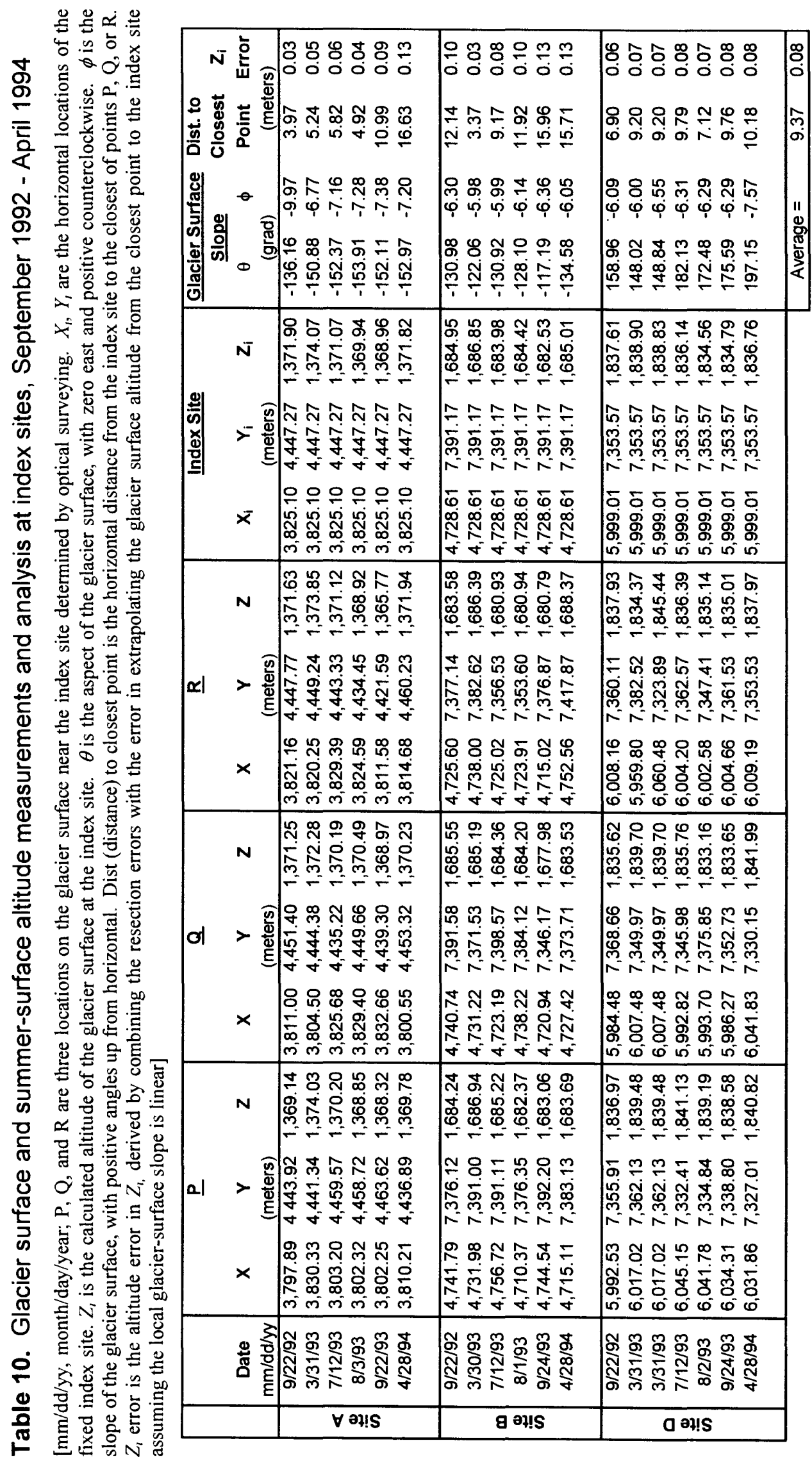




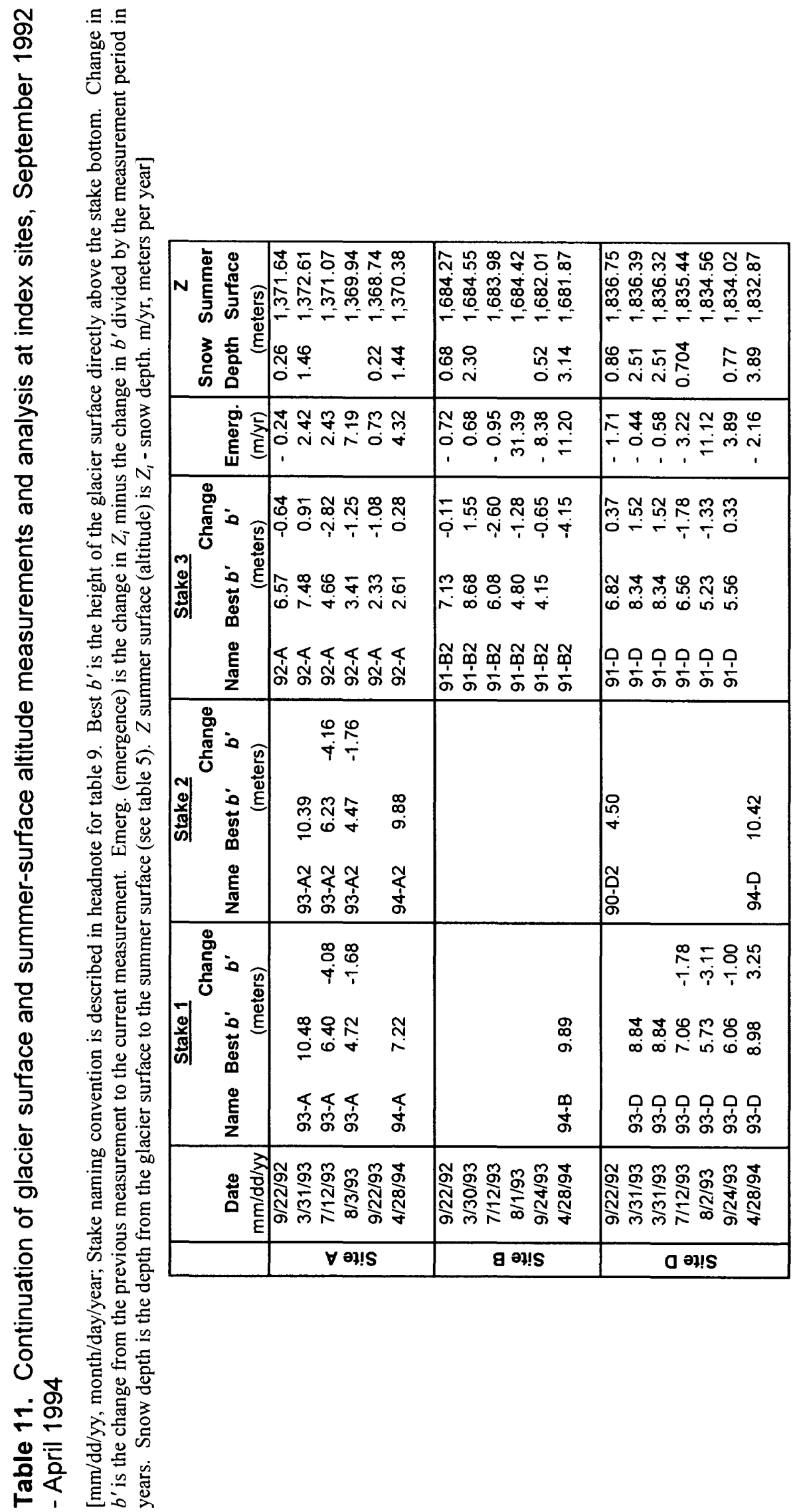

28 Mass Balance, Meteorological, Ice Motion. Surface Altitude, and Runoff Data at Gulkana Glacier, Alaska, 1993 Balance Year 


\section{REFERENCES CITED}

Braithwaite, R.J., and Olesen, O.B., 1985, Ice ablation in West Greenland in relation to air temperature and global radiation: Zeitschrift Für Gletscherkunde Und Glazialgeologie, v. 20, no. 1984, p. 155-168.

Braithwaite, R.J., and Olesen, O.B., 1993, Seasonal variation of ice ablation at the margin of the Greenland ice sheet and its sensitivity to climate change, Qamanârssûp sermia, West Greenland: Journal of Glaciology, v. 39, no. 132, p. 267-274.

Fahl, C.B., 1973, Some relationships between glaciers and climate in Alaska: Fairbanks, Alaska, University of Alaska, Ph.D. dissertation, $191 \mathrm{p}$.

Fountain, A.G., Krimmel, R.M., and Trabant, D.C., 1997, Glacier monitoring program of the U.S. Geological Survey: U.S. Geological Survey Circular 1132, 19 p.

Haeberli, Wilfried, 1985, Fluctuations of glaciers 1975-1980 (Vol. IV): International Association of Hydrologic Sciences (International Commission of Snow and Ice) and United Nations Educational, Scientific and Cultural Organization, 265 p., maps, and plates.

Haeberli, Wilfried, and Hoelzle, Martin, 1993, Fluctuations of glaciers 1985-1990 (Vol. VI): International Association of Hydrologic Sciences (International Commission on Snow and Ice) and United Nations Environment Programme and United Nations Educational, Scientific and Cultural Organization, 322 p., maps, and plates.

Haeberli, Wilfried, and Müller, Peter, 1988, Fluctuations of glaciers 1980-1985 (Vol. V): International Association of Hydrologic Sciences (International Commission on Snow and Ice) and United Nations Environment Programme and United Nations Educational, Scientific and Cultural Organization, 290 p., maps, and plates.

Karl, T.H., Tarpley, J.D., Quayle, R.G., Diaz, H.F., Robinson, D.A., and Bradley, R.S., 1989, Recent climate record: What it can and cannot tell us: Reviews of Geophysics, v. 27, no. 3, p. 405-430.

Kasser, Peter, 1967, Fluctuations of glaciers 1959-1965 (Vol. I): International Association of Scientific Hydrology (International Commission of Snow and Ice) and United Nations Educational, Scientific and Cultural Organization (no pagination).

Kennedy, B.W., 1995, Air temperature and precipitation data, Wolverine Glacier Basin, Alaska, 1967-94: U.S. Geological Survey Open-File Report 95-444, 79 p. and diskette.

Letréguilly, Anne, and Reynaud, Louis, 1989, Spatial patterns of mass-balance fluctuations of North American Glaciers: Journal of Glaciology, v. 35, no. 120, p. 163-168.

Linn, K.R., Kemnitz, R.T., Bailey, B.J., Rickman, R.L., and Swanner, W.C., 1994, Water resources data, Alaska, water year 1993: U.S. Geological Survey Water-Data Report AK-93-1, 373 p.

March, R.S., and Trabant, D.C., 1996, Mass balance, meteorological, ice motion, surface altitude, and runoff data at Gulkana Glacier, Alaska, 1992 balance year: U.S. Geological Survey Water-Resources Investigations Report 95$4277,32 \mathrm{p}$.

Mayo, L.R., 1986, Annual runoff rate from glaciers in Alaska; a model using the altitude of glacier mass balance equilibrium, in Kane, D.L., ed., Cold Regions Hydrology Symposium, Fairbanks, 1986, Proceedings: American Water Resources Association, p. 509-517.

Mayo, L.R., 1992, Internal ablation - An overlooked component of glacier mass balance [abs.]: EOS, Transactions, American Geophysical Union, v. 73, no. 43, Supplement, p. 180

Mayo, L.R., March, R.S., and Trabant, D.C., 1992, Air temperature and precipitation data, 1967-88, Wolverine Glacier basin, Alaska: U.S. Open-File Report 91-246, 80 p.

Mayo, L.R., Meier, M.F., and Tangborn, W.V., 1972, A system to combine stratigraphic and annual mass-balance systems: A contribution to the International Hydrologic Decade: Journal of Glaciology, v. 11, no. 61, p. 3-14.

Mayo, L.R., and Trabant D.C., 1982, Geodetic trisection, altitude, and ice-radar surveying techniques used at Knik Glacier, Alaska and summary of 1979, 1980, and 1981 data: U.S. Geological Survey Open-File Report 82-685, $26 \mathrm{p}$. 
Mayo, L.R., and Trabant D.C., 1986, Recent growth of Gulkana Glacier, Alaska Range, and its relation to glacier-fed runoff, in Subitsky, Seymour, ed., Selected papers in the hydrologic sciences: U.S. Geological Survey Water-Supply Paper 2290, p. 91-99.

Mayo, L.R., Trabant, D.C., March, Rod, and Haeberli, Wilfried, 1979, Columbia Glacier stake locations, mass balance, glacier surface altitude, and ice radar data, 1978 measurement year: U.S. Geological Survey Open-File Report 79-1168, $72 \mathrm{p}$.

Meier, M.F., Mayo, L.R., Trabant, D.C., and Krimmel, R.M., 1980, Comparison of mass balance and runoff at four glaciers in the United States, 1966 to 1977: Academy of Sciences of USSR, Section of Glaciology, Data of Glaciological Studies, Publication No. 38, p. 138-147 (Russian text with figures), p. 214-219 (English text).

Meier, M.F., Tangborn, W.V., Mayo, L.R., and Post, Austin, 1971, Combined ice and water balances of Gulkana and Wolverine Glacier, Alaska, and South Cascade Glacier, Washington, 1965 and 1966 hydrologic years: U.S. Geological Survey Professional Paper 715-A, 23 p.

Muller, Fritz, 1977, Fluctuations of glaciers 1970-1975 (Vol. III): International Association of Hydrologic Sciences (International Commission of Snow and Ice) and United Nations Educational, Scientific and Cultural Organization, 269 p., maps, and plates.

National Climatic Data Center, 1996, Climatological data annual summary, Alaska, 1995: v. 81, no. 13, 23 p.

Østrem, G., and Brugman, M., 1991, Glacier mass-balance measurements: a manual for field and office work: Environment Canada, National Hydrology Research Institute Science Report No. 4, 224 p.

Østrem, G. and Stanley, A.D., 1969, Glacier and mass balance measurements, a manual for field and office work, revised edition: Canadian Department of Energy, Mines, and Resources and Norwegian Water Resources and Electricity Board, IWB Reprint Series No. 66, Inland Waters Branch, Department of the Environment, Ottawa, Ontario, $118 \mathrm{p}$.

Péwé, T.L., and Reger, R.D., 1983, Delta River area, Alaska Range, in Péwé, T.L., and Reger, R.D., eds., Guidebook to permafrost and Quaternary geology along the Richardson and Glenn Highways between Fairbanks and Anchorage, Alaska-Guidebook 1, Fourth International Conference on Permafrost: Alaska Division of Geological and Geophysical Surveys, p. 47-135.

Tangborn, W.V., Mayo, L.R., Scully, D.R., and Krimmel, R.M., 1977, Combined ice and water balances of Maclure Glacier, California, South Cascade Glacier, Washington, and Wolverine and Gulkana Glaciers, Alaska-1967 hydrologic year: U.S. Geological Survey Professional Paper 715-B, 20 p.

Trabant, D.C., and Mayo, L.R., 1985, Estimation and effects of internal accumulation on five glaciers in Alaska: Annals of Glaciology, v. 6, p. 113-117.

United Nations Educational, Scientific, and Cultural Organization/International Association of Scientific Hydrology, 1970, Combined heat, ice and water balances at selected glacier basins: Paris, United Nations Educational, Scientific, and Cultural Organization/International Association of Scientific Hydrology, Technical Papers in Hydrology $5,20 \mathrm{p}$.

U.S. Departments of the Army and the Air Force, 1951, TM 5-241- to 16-1-233, The Universal Grid Systems (Universal Transverse Mercator) and (Universal Polar Stereographic): Washington, Government Printing Office, $324 \mathrm{p}$.

Walters, R.A., and Meier, M.F., 1989, Variability of glacier mass balances in western North America, in Peterson, D.H., Aspects of climate variability in the Pacific and Western Americas: American Geophysical Union, Geophysical Monograph 55, p. 365-374.

Warnick, C.C., 1953, Experiments with windshields for precipitation gages: Transactions, American Geophysical Union, v. 34 , no. 3 , p. 379-388. 